\title{
Flexible and versatile pincer-type PGeP and PSnP ligand frameworks
}

\author{
Sebastian Bestgen, Nicholas H. Rees, and Jose M. Goicoechea* \\ Department of Chemistry, Chemistry Research Laboratory, University of Oxford, 12 Mansfield Road, OXı 3TA, Ox- \\ ford, Oxfordshire, United Kingdom.
}

Germylenes - Stannylenes - Phosphines - Pincer ligands - Transition metals

\begin{abstract}
We describe the synthesis and application of two phosphine-functionalized pincer-type N-heterocyclic carbene analogues $[(\mathrm{PNNP}) \mathrm{E}](\mathrm{E}=\mathrm{Ge}, \mathrm{Sn})$ and their reactivity towards main group and precious metal compounds. These flexible tetrelene ligands feature unusual coordination geometries, strong P-E interactions and are expandable to digermylene or distannylene compounds on reaction with $\mathrm{ECl}_{2}$. The compounds were also successfully applied as ligands for the synthesis of $\mathrm{Cu}, \mathrm{Ag}, \mathrm{Au}$ and $\mathrm{Pt}$ complexes. The inherent flexibility of the ligand scaffold enabled different structural arrangements driven by the coordination requirements of the metal centres and intermetallic interactions.
\end{abstract}

\section{INTRODUCTION}

$\mathrm{N}$-Heterocyclic carbenes (NHCs) have attracted considerable attention during the last decades and are commonly used in as ligands in transition metal and main group chemistry due to their strong donor properties. ${ }^{1}$ Metal complexes of NHC ligands are now widely used in a number of applications including homogeneous catalysis. ${ }^{2-5}$ As they commonly act as monodentate $\sigma$-donor ligands, a variety of ligand modifications have been developed in order to functionalize NHCs with additional donor sites $(\mathrm{O}, \mathrm{N}, \mathrm{P}$ etc.) to obtain pincer-type or chelating carbenebased ligand systems. ${ }^{6-10}$ In contrast, functionalized heavier carbene analogues of the group 14 elements ( $\mathrm{Si}$ : silylenes, Ge: germylenes, $\mathrm{Sn}$ : stannylenes, $\mathrm{Pb}$ : plumbylenes) are far less developed despite the fact that the first saturated N-heterocyclic germylene $\mathrm{Ge}\left\{\left(\mathrm{N}^{t} \mathrm{Bu}\right)_{2} \mathrm{C}_{2} \mathrm{H}_{4}\right\}$ was reported by Herrmann and coworkers as early as 1992. ${ }^{11.12}$ Generally, pincer-type ligands are an intensely investigated class of compounds as they often provide an excellent balance of stability and reactivity. ${ }^{13}$ Given that heavier tetrelene ligands can also act as strong electron-donating ligands, ${ }^{1-18}$ efforts have been made to develop novel pincer-type tetrelene ligands and to utilize them in combination with transition metals for various catalytic transformations. ${ }^{19-24}$ However, so far they are limited to ECE or ENE systems $(\mathrm{E}=\mathrm{Si}, \mathrm{Ge})$ and only very recently, the first phosphine-functionalized germylene and stannylene ligands and their applications have been reported. ${ }^{25-28}$ Given that polydentate carbene ligands and their polymetallic complexes often feature interesting properties such as photoluminescent behavior, ${ }^{29-31}$ we were interested in substituting the carbene carbon atom by its heavier analogues and explore the properties of such compounds. Thereby, we used a PNHNHP proligand developed by Thomas and co-workers (pictured in
Scheme 1), whose synthesis is straightforward, feasible on a multi-gram scale and has been extensively investigated. ${ }^{32-39}$

\section{RESULTS AND DISCUSSION}

We treated the pro-ligand PNHNHP with two equivalents of KHMDS and the corresponding divalent metal salts, $\left[\mathrm{GeCl}_{2}\right.$ (dioxane) $]$ and anhydrous $\mathrm{SnCl}_{2}$, in an simple one-pot reaction (Scheme 1). After workup, both complexes [(PNNP)E] $(\mathrm{E}=\mathrm{Ge}(\mathbf{1}), \mathrm{Sn}(\mathbf{2}))$ were isolated as large single crystals in reasonable to good yields, and were found to be stable under inert conditions.

Scheme 1. Synthesis of the carbene analogues [(PNNP)E] (E = Ge (1), Sn (2)).

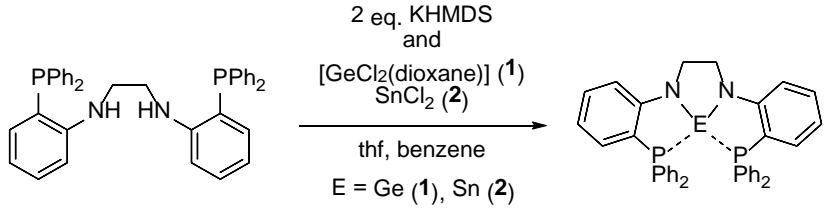

In the ${ }^{1} \mathrm{H}$ NMR spectrum of $\mathbf{1}$, the clear absence of the amine- $\mathrm{H}$ resonance indicates successful deprotonation of the diamine pro-ligand. A single resonance for the ethylene backbone is observed at $3.49 \mathrm{ppm}$ suggesting a symmetric conformation in solution. This assumption is strengthened by the ${ }^{13} \mathrm{C}\left\{{ }^{1} \mathrm{H}\right\}$ NMR spectrum in which triplets are observed for aromatic carbon atoms caused by virtual coupling to the ${ }^{31} \mathrm{P}$ nuclei. Indeed, the ${ }^{31} \mathrm{P}\left\{{ }^{1} \mathrm{H}\right\}$ spectrum of 1 reveals a singlet at $-21.1 \mathrm{ppm}$ proving that both phosphine units are isochronous and that $\sigma_{\mathrm{v}}$-symmetry is maintained in solution. Compared to PNHNHP (-23.3 $\mathrm{ppm})$, the resonance is only slightly shifted downfield. For the stannylene, [(PNNP)Sn] (2), we exploited the favorable NMR characteristics of tin. While the ${ }^{1} \mathrm{H}$ spectra of 2 
are comparable to $\mathbf{1}$, resonances in the ${ }^{13} \mathrm{C}\left\{{ }^{1} \mathrm{H}\right\}$ spectrum are broadened due to unresolved coupling with ${ }^{31} \mathrm{P}$ and ${ }^{117,119} \mathrm{Sn}$. In the ${ }^{31} \mathrm{P}\left\{{ }^{1} \mathrm{H}\right\}$ spectrum, a singlet is centered at $20.3 \mathrm{ppm}$ flanked by ${ }^{117} \mathrm{Sn} /{ }^{119} \mathrm{Sn}$ satellites. The measured ${ }^{1} J_{\mathrm{P}}$ Sn values account for ${ }^{1} J_{117} \mathrm{Sn}-\mathrm{P}=1295 \mathrm{~Hz}$ and ${ }^{1} J_{119 \mathrm{Sn}-\mathrm{P}}=1355$ Hz. In agreement with ${ }^{31} \mathrm{P}\left\{{ }^{1} \mathrm{H}\right\}$ NMR data, a triplet is observed in the ${ }^{119} \mathrm{Sn}\left\{{ }^{1} \mathrm{H}\right\}$ NMR spectrum at $-270 \mathrm{ppm}$ with a ${ }^{1} J_{\mathrm{P}-\mathrm{Sn}}$ coupling constant of $1348 \mathrm{~Hz}$. Both the chemical shift as well as coupling constants range between those found for comparable tin (IV) and tin (II) complexes $\left[(\mathrm{PNP}) \mathrm{SnCl}_{3}\right]\left(\delta\left({ }^{119} \mathrm{Sn}\right)=-500 \mathrm{ppm},{ }^{1} J_{119 \mathrm{Sn}-\mathrm{P}}=1672 \mathrm{~Hz}\right),{ }^{1}{ }_{117} \mathrm{Sn}-$ $\mathrm{P}=1597 \mathrm{~Hz})$ and $\left[(\mathrm{PNP}) \operatorname{Sn}\left\{\mathrm{N}\left(\mathrm{SiMe}_{3}\right)_{2}\right\}\right]\left(\delta\left({ }^{119} \mathrm{Sn}\right)=-177\right.$ ppm, ${ }^{1} J_{119 S n-P}=585$ and $\left.{ }^{1} J_{119} \mathrm{Sn}-\mathrm{P}=978 \mathrm{~Hz}\right),{ }^{1} J_{117} \mathrm{Sn}-\mathrm{P}=548$ and $\left.{ }^{1} J_{117 \mathrm{Sn}-\mathrm{P}}=931 \mathrm{~Hz}\right)\left(\mathrm{PNP}=\mathrm{N}-\left[2-\mathrm{P}(i-\mathrm{Pr})_{2}-4\right.\right.$-methylphenyl $\left.{ }_{2}{ }^{-}\right)$ reported by Wesemann and coworkers. ${ }^{40}$ Compared to $\left[(\mathrm{PNP}) \mathrm{Sn}\left\{\mathrm{N}\left(\mathrm{SiMe}_{3}\right)_{2}\right\}\right]$ and $\mathrm{Sn}\left\{\left(\mathrm{NCH}_{2} \mathrm{P}^{t} \mathrm{Bu}_{2}\right)_{2} \mathrm{C}_{6} \mathrm{H}_{4}\right\} \quad\left({ }^{1} J_{119} \mathrm{Sn}-\mathrm{P}\right.$ $=647 \mathrm{~Hz}),{ }^{27}$ the significantly larger coupling constant for $\mathbf{2}$ suggests stronger bonding of the phosphine moieties to the divalent tin center. Compounds 1 and $\mathbf{2}$ were characterized by single crystal X-ray analysis. Both compounds are isostructural and crystalize in the triclinic space group $P \overline{1}$ with a single molecule in the asymmetric unit (Figure 1).
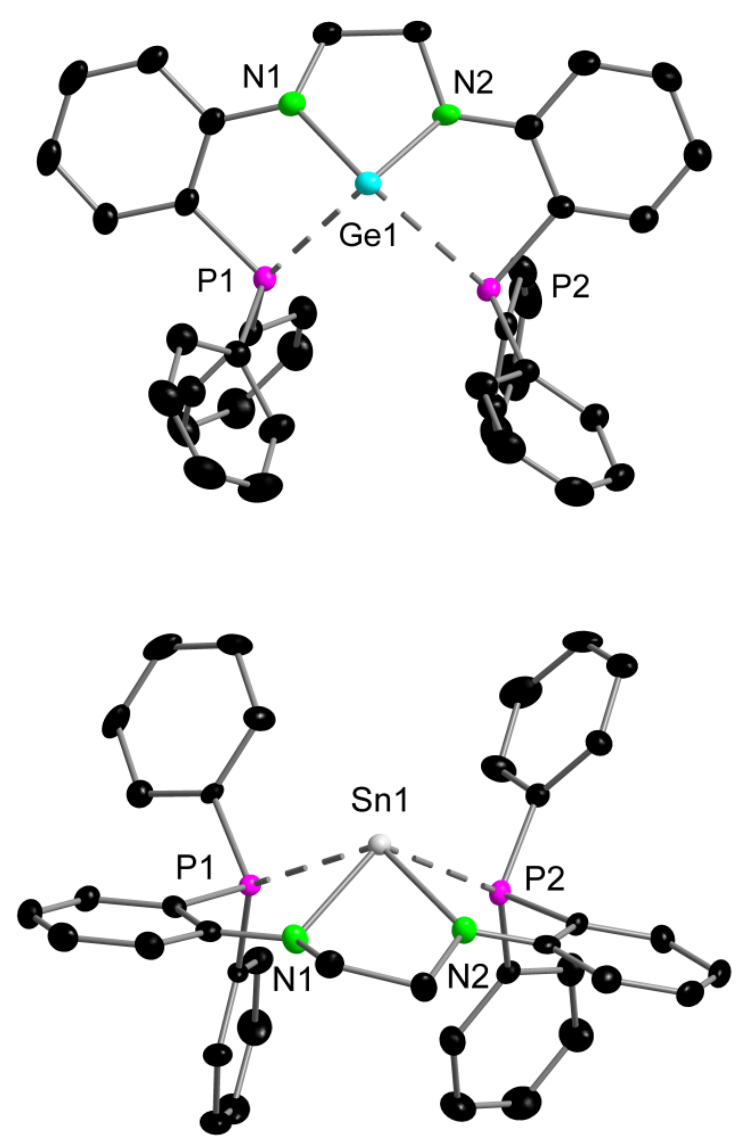

Figure 1. Molecular structures of 1 (top) and 2 (bottom) in the solid state. The thermal ellipsoids are set at a 50\% probability level. Solvent molecules and hydrogen atoms are omitted for clarity.
The saturated $\mathrm{N}$-heterocyclic germylene and stannylene systems feature a divalent metal centre as tip of a pyramidal coordination environment. With $\mathrm{N}_{1}-\mathrm{C}_{1}-\mathrm{C}_{2}-\mathrm{N}_{2}$ torsion angles of $37.09^{\circ}(\mathbf{1})$ and $37.80^{\circ}(\mathbf{2})$, the ligand backbone adopts a bent structure (indicating a certain degree of flexibility) and binds to the metal atoms in a clinched rectangular fashion ( $\mathrm{N}_{1}-\mathrm{Ge}_{1}-\mathrm{N}_{2}$ 83.11 $\left.{ }^{\circ}, \mathrm{N}_{1}-\mathrm{Sn}_{1}-\mathrm{N}_{2} \quad 76.23^{\circ}\right)$. As expected, the bite angles are significantly decreased compared to e.g. the lighter saturated homologues 1,3bis(2,4,6-trimethylphenyl)-4,5-dihydroimidazol-2-ylidene (SIMes) (N-C-N 104.7(3) $)^{\circ}$ and N,N'-1,3-di-t-butylimidazol2-silylene $\left(\mathrm{N}-\mathrm{Si}-\mathrm{N} 92.0^{\circ}\right) .^{4^{1-42}}$ For 1, Ge-N bond distances are $1.929(2) \AA\left(\mathrm{Ge} 1-\mathrm{N}_{1}\right)$ and 1.949(2) $\AA$ (Ge1-N2), which are slightly longer compared to e.g. [Fc(NMes) ${ }_{2} \mathrm{Ge}$ ] (Ge1N1 1.8459(14) $\AA$ and Ge1-N2 1.8443(14) $\AA$ ). ${ }^{43}$ In case of the tin system 2, both $\mathrm{Sn}-\mathrm{N}$ bond lengths (Sn1-N1 2.157(4) $\AA$ and $\mathrm{Sn} 1-\mathrm{N}_{2} 2.17 \mathrm{O}(4) \AA$ ) are also elongated compared to those found in $\mathrm{N}$-heterocyclic stannylenes such as $N, N^{\prime}$ 1,3-dimesitylimidazol-2-stannylene (Sn1-N2 2.084(3) A, Sn1-N5 2.102(3) Å, mesityl = 2,4,6-trimethylphenyl). ${ }^{44}$ As evidenced by NMR studies, the phosphine moieties coordinate to the $\mathrm{Ge} / \mathrm{Sn}$ atoms also in the solid state. For $\mathbf{1}$, remarkably short Ge-P distances of Ge1-P1 2.6374(6) $\AA$ and Ge1-P2 $2.8700(6) \AA$ are observed indicating a significant dative interaction between the phosphine and the metal. Both Ge-P distances are clearly shorter than those found in the DFT-optimized structure of $\mathrm{Ge}\left\{\left(\mathrm{NCH}_{2} \mathrm{P}^{t} \mathrm{Bu}_{2}\right)_{2} \mathrm{C}_{6} \mathrm{H}_{4}\right\}(\mathrm{Ge}-\mathrm{P} 3.362 \AA)$, in which a weak long-distance orbital interaction rather than an electrostatic one was suggested. ${ }^{25}$ In the case of $\mathbf{2}$, comparable Sn-P distances (Sn1-P1 2.8386(10) $\AA$ and Sn1-P2 2.7620(10) $\AA$ ) are observed despite the larger ionic radius of $\mathrm{Sn}(\mathrm{II})$. They are also shorter compared to those found in $\left[(\mathrm{PNP}) \operatorname{Sn}\left\{\mathrm{N}\left(\mathrm{SiMe}_{3}\right)_{2}\right\}\right] \quad\left(\mathrm{Sn}-\mathrm{P}_{1} \quad 2.9698(7) \quad \AA, \quad \mathrm{Sn}-\mathrm{P}_{2}\right.$ $2.8820(7) \AA$ ) and $\mathrm{Sn}\left\{\left(\mathrm{NCH}_{2} \mathrm{P}^{t} \mathrm{Bu}_{2}\right)_{2} \mathrm{C}_{6} \mathrm{H}_{4}\right\}$ (Sn-P 3.277(1) $\AA$ and 3.313(1) $\AA$ ), and similar to $\mathrm{Sn}-\mathrm{P}$ distances in a benzene-based Lewis Pair [( $\left.\left.\operatorname{Trip}_{2}\left(\mathrm{C}_{6} \mathrm{H}_{3}\right) \mathrm{Sn}\right)\left(\mathrm{PPh}_{2}\right) \mathrm{C}_{6} \mathrm{H}_{4}\right](\mathrm{Sn}-\mathrm{P}$ 2.7489(4) Aं; Trip = $\left.\mathrm{C}_{6} \mathrm{H}_{2}-2,4,6-\mathrm{Pr}_{3}\right) .{ }^{27,40,45}$ For comparison, in the benzylphosphine-substituted stannylene featuring a three-membered Sn-C-P ring (Sn-P 2.663(1) Å), a stronger $\mathrm{Sn}-\mathrm{P}$ interaction is observed and described as donor-acceptor interaction of the $\mathrm{P}$ lone pair donating into a tin p-orbital. ${ }^{46}$ We thus suggest that donoracceptor interactions of both phosphorus-based lone pairs and the divalent Ge/Sn centre are also present in our case.

With our pincer-type ligands in hand, we next investigated their coordination behavior towards different main group and precious metal compounds. Given our interest in group 14 complexes, 47 we reacted 1 and 2 with their parent metal halides $\left[\mathrm{GeCl}_{2}\right.$ (dioxane) $]$ and $\mathrm{SnCl}_{2}$, respectively (Scheme 2). Complex 1 was first reacted with $\left[\mathrm{GeCl}_{2}\right.$ (dioxane)] in a 1:1 ratio in hot benzene. After concentration of the mother liquor, colorless crystals were obtained and subjected to X-ray structural analysis. Surprisingly, instead of an germylene- $\mathrm{GeCl}_{2}$ adduct, a digermylene $\left[(\mathrm{PNNP})(\mathrm{GeCl})_{2}\right]$ (3) with two $\mathrm{RGeCl}$ moieties formed (Figure 2, top). Upon reaction with $\mathrm{GeCl}_{2}$, halide transfer from the dichloride to [(PNNP)Ge] occurs to- 
gether with decomplexation of the originally fourcoordinate $\mathrm{Ge}$ center, to afford two $\mathrm{PN}-\mathrm{GeCl}$ units. The $\mathrm{Ge}$ atoms are now three-coordinate each binding to $\mathrm{Cl}$ and one PN pocket. Obviously, the unsaturated ethylene backbone allows for opening of the all-chelating mode to an open-chain-type structure thus implying a strong degree of ligand flexibility with respect to structural arrangement and coordination sites. Complex 3 crystallizes in the monoclinic space group $P_{2_{1}} / n$ with half a molecule in the asymmetric unit.

Scheme 2. Synthesis of the digermylene and distannylene $\left[(\mathrm{PNNP})(\mathrm{ECl})_{2}\right] 3(\mathrm{E}=\mathrm{Ge})$ and $4(\mathrm{E}=\mathrm{Sn})$ upon opening of the parent pincer-type compounds.
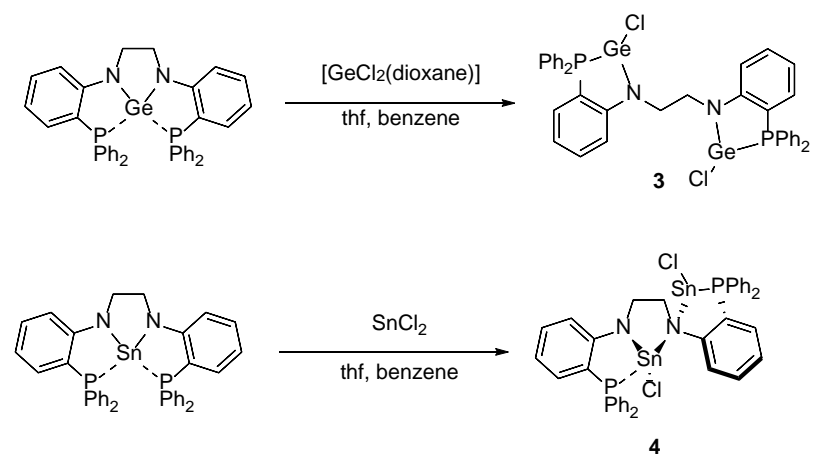

While the Ge-N bond distances (Ge1-N1 1.934(3) ̊̊) are maintained, Ge-P distances shorten significantly upon changing the coordination mode: Ge-P 2.4437(12) A. This is approximately $1 \AA$ shorter compared to the P-Ge distances in the calculated structure of $\mathrm{Ge}\left\{\left(\mathrm{NCH}_{2} \mathrm{P}^{t} \mathrm{Bu}_{2}\right)_{2} \mathrm{C}_{6} \mathrm{H}_{4}\right\}$.

In the case of the heavier tin analogue, similar reactivity is observed between 2 and $\mathrm{SnCl}_{2}$. Again, halide transfer from $\mathrm{SnCl}_{2}$ to [(PNNP)Sn] and the formation of a dinuclear complex occurred, but structural analysis revealed a different connectivity compared to 3 . In the distannylene $\left[(\mathrm{PNNP})(\mathrm{SnCl})_{2}\right](4)$, two different coordination modes of the Sn centers are observed (Figure 2, bottom). With regards to bond lengths, angles and coordination geometries, 4 can be seen as an intermediate between the pincer-type and the open-chain-type structure. Snı features a seesaw molecular geometry with one short Snı-N1 bond (2.172(3) $\AA$ ), which is fairly identical to 2, and one clearly elongated $\mathrm{Sn} 1-\mathrm{N}_{2}$ bond (2.518(3) Å). Correspondingly, Sn1-P1 (2.7732(7) $\AA$ ) remains unaffected, while Sn2-P2 $2.6775(8) \AA$ is shortened due to the decrease in the coordination number of Sn2. In $4, \mathrm{~N}_{2}$ acts as a bridging $\mu^{2}-$ donor site and, in contrast to $\mathrm{N}$, adopts a tetrahedral conformation (Sn1-N2-Sn2 $106.48(10)^{\circ}, \quad \mathrm{C}_{2}-\mathrm{N}_{2}-\mathrm{Sn}_{2}$ $\left.111.8(2)^{\circ}\right)$. N2 forms a short covalent bond to $\mathrm{Sn}_{2}(2.288(3)$ $\AA$ ) and acts as a dative ligand to $\mathrm{Sn} \mathrm{b}$ by its lone pair. Thus, the PNNP ligand is able to act as a pincer-type ligand as well as a flexible polydentate ligand for bimetallic compounds. A decrease in coordination numbers accompanies shortening of $\mathrm{M}-\mathrm{P}$ bonds while $\mathrm{M}-\mathrm{N}$ bonds remain almost unaffected. The saturated ethylene backbone enables a flexible bending mode of the ligand scaffold as evidenced by the difference in torsion angles (2: $\mathrm{N}_{1}-\mathrm{C}_{1}-\mathrm{C}_{2}-$ $\left.\mathrm{N}_{2} 37.8^{\circ}, 4: \mathrm{N}_{1}-\mathrm{C}_{1}-\mathrm{C}_{2}-\mathrm{N}_{2} 56.9^{\circ}\right)$. Compounds 3 and 4 are poorly soluble in common organic solvents, which hampered a detailed analysis via NMR spectroscopy. However, ${ }^{3} \mathrm{P}\left\{{ }^{1} \mathrm{H}\right\}$ NMR spectra in pyridine- $d_{5}$ reveal resonances at very similar shifts (3: $-21.6 \mathrm{ppm} ; 4$ : $-19.8 \mathrm{ppm})$ to their parent compounds. Additionally, CP-MAS NMR spectra were recorded for $\mathbf{2}$ and $\mathbf{4}$ (see SI for details). In the crystal structure of 2, the two phosphorus atoms in each molecule are inequivalent and therefore give separate peaks in ${ }^{11} \mathrm{P}$ spectrum both of which exhibit ${ }^{11 / 119} \mathrm{Sn}$ satellites $\left({ }^{1} \mathrm{~J}_{\mathrm{P}-}\right.$ $\mathrm{Sn}=1423 \mathrm{~Hz}$ and ${ }^{1} \mathrm{~J}_{\mathrm{P}-\mathrm{Sn}}=1436 \mathrm{~Hz}$ ). The ${ }^{19} \mathrm{Sn}$ spectrum has one resonance which appears as a triplet due to coupling to the two ${ }^{31} \mathrm{P}$ nuclei. Complex 4 contains two different phosphorus and tin environments, which are reflected in the ${ }^{19} \mathrm{Sn}$ and ${ }^{11} \mathrm{P}$ spectra, each of which contain two resonances. For ${ }^{19} \mathrm{Sn}$, the chemical shifts account for -272.3 ppm and $-296.5 \mathrm{ppm}$, whereas ${ }^{31} \mathrm{P}$ resonances are observed at $0.6 \mathrm{ppm}$ and $-15.6 \mathrm{ppm}$ with ${ }^{1} \mathrm{JP}_{\mathrm{P}-\mathrm{Sn}}=2039 \mathrm{~Hz}$ and ${ }^{1} J_{\mathrm{P}-\mathrm{Sn}}=955 \mathrm{~Hz}$, respectively. The linewidth of the ${ }^{119} \mathrm{Sn}$ spectrum only allows the larger coupling to be resolved on the resonance at $-272.3 \mathrm{ppm}$.
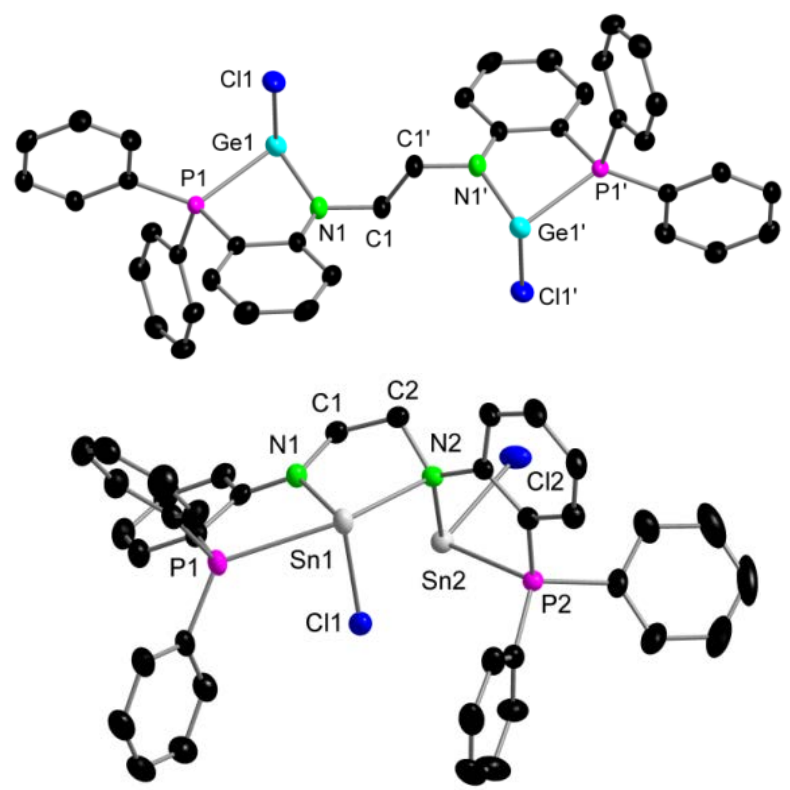

Figure 2. Molecular structures of $\left[(\mathrm{PNNP})(\mathrm{GeCl})_{2}\right]$ (3, top) and $\left[(\mathrm{PNNP})(\mathrm{SnCl})_{2}\right](4$, bottom) in the solid state. The thermal ellipsoids are set at a 50\% probability level. Solvent molecules and hydrogen atoms are omitted for clarity.

We next felt inclined to investigate the coordination behavior of the phosphine-functionalized heavier carbene analogues towards coinage metal salts. Upon reaction of $[(\mathrm{PNNP}) \mathrm{Ge}] \mathbf{1}$ with one equivalent $\mathrm{CuCl}$ in toluene and subsequent concentration of the clear colorless solution, single crystals were directly obtained from the mother liquor and subjected to X-ray structural analysis (Scheme 3). Instead of a monomeric species, a dimeric complex $[(\mathrm{PNNP}) \mathrm{GeCu}(\mu-\mathrm{Cl})]_{2} \mathbf{5}$ was obtained. 
Scheme 3. Synthesis of the dimeric coinage metal complexes $[(\mathrm{PNNP}) \mathrm{GeM}(\mu-\mathrm{Cl})]_{2}(\mathrm{M}=\mathrm{Cu} \quad(5), \mathrm{Ag}(6))$ and $\left[\left\{(\mathrm{PNNP}) \mathrm{GeCl}_{2} \mathrm{Au}_{2}\right](7)\right.$.

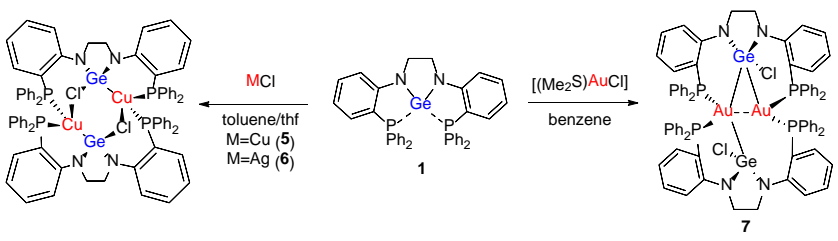

Complex 5 crystallizes in the monoclinic space group $P_{2_{1}} / c$ with one molecule in the asymmetric unit (Figure 3, top). The central part consists of an inorganic six membered $[\mathrm{GeCuCl}]_{2}$ ring, which adopts a boat-type conformation. Each $\mathrm{Cu}$ atom is bound to two phosphine ligands with $\mathrm{Cu}-\mathrm{P}$ bond distances ranging between 2.2541(6) $\AA$ and 2.3005(5) $\AA$, and one germylene with Cu1-Ge1 2.3554(3) $\AA$ and Cu2-Ge2 2.3451(3) $\AA$. These $\mathrm{Cu}-\mathrm{Ge}$ distances are longer compared to e.g. $\left[\mathrm{M}_{4}\left(\mu^{3}-\right.\right.$ $\left.\mathrm{Cl})_{4}\left\{\mathrm{Ge}\left({ }^{t} \mathrm{Bu} \mathrm{b}_{2} \text { bzam }\right)^{t} \mathrm{Bu}\right\}_{4}\right] \quad\left({ }^{t} \mathrm{Bu}_{2}\right.$ bzam $=N, N^{\prime}$-di(tertbutyl $)$ benzamidinate) (Ge-Cu 2.2765(9) $\AA$ )..$^{8}$ The chloride ions adopt a $\mu^{2}$-bridging position and link the two adjacent $\{\mathrm{GeCu}\}$-units almost symmetrically $(\mathrm{M}-\mathrm{Cl}: 2.3696(5)-$ 2.4213(5) $\AA$ ). Due the long intermetallic distances (Cu1Cu2 4.0948(6) $\AA$ and Ge1-Ge2 3.9206(7) $\AA$ ), transannular bonding interactions are excluded. The Ge1-Cu1-Gez-Cuz torsion angle $\left(4.2^{\circ}\right)$ indicates an almost rectangular arrangement of the metal centers.

It is noteworthy that the dimeric structure is not caused by bridging chloride ions or intermolecular interactions of two monomeric species, but rather by the phosphine units of one ligand backbone binding to two different $\mathrm{Cu}$ ions to form an inorganic macrocyclic structure. The flexibility of the PNNPGe ligand is thus not only illustrated by the $\mathrm{N}_{1}-\mathrm{C}_{1}-\mathrm{C}_{2}-\mathrm{N}_{2}$ torsion angle $\left(48.1^{\circ}\right.$ for 5 ) but also by its ability to form macrocyclic and polymetallic compounds. Adopting the same reaction conditions, the corresponding silver complex $[(\mathrm{PNNP}) \mathrm{GeAg}(\mu-\mathrm{Cl})]_{2} \mathbf{6}$ was accessible from [(PNNP)Ge] and $\mathrm{AgCl}$ (Figure 3, middle). The structural analysis (orthorhombic chiral space group $\left.P_{2} 2_{1} 2_{1}\right)$ revealed the same connectivity as in 5 , but a slightly distorted structure. While again a boat-type conformation of the $(\mathrm{GeAgCl})_{2}$ ring with two $\mu^{2}$-bridging $\mathrm{Cl}^{-}$ ions is observed, both $\{\mathrm{GeAg}\}$ dumbbells are twisted against each other (Ge1-Ag1-Ge2-Ag2 16. $5^{\circ}$ ) (Figure 4). Ge$\mathrm{Ag}$ bond lengths account for Ag1-Ge1 2.5092(8) $\AA$ and Ag2-Ge2 2.5206(8) $\AA$ and are comparable to those found in e.g. $\left[(\mathrm{LGeCCPh})_{2} \mathrm{Ag}\right]\left[\mathrm{Ag}\left(\mathrm{C}_{6} \mathrm{~F}_{5}\right)_{2}\right](\mathrm{L}=\mathrm{HC}[\mathrm{C}(\mathrm{Me}) \mathrm{N}-2,6-$ $\left.\left.i \mathrm{Pr}_{2} \mathrm{C}_{6} \mathrm{H}_{3}\right]_{2}\right) \quad(\mathrm{Ge}-\mathrm{Ag}$ 2.4731(10) $\AA$ and 2.4732(10)) $\AA$ or $\left[\mathrm{Ag}\left\{\mathrm{Ge}\left({ }^{t} \mathrm{Bu}_{2} \mathrm{bzam}\right)^{t} \mathrm{Bu}\right\}_{2}\right]\left[\mathrm{BF}_{4}\right](\mathrm{Ge}-\mathrm{Ag} 2.4539(3) \AA) .{ }^{48,49} \mathrm{In}$ contrast to $5, \mathrm{M}-\mathrm{Cl}$ bond lengths are no longer equal. Normal Ge-Cl distances (Ge1-Cl1 2.367(2) $\AA$ and Ge2-Cl2 2.3762(14) $\AA$ ) are found, while $\mathrm{Ag}-\mathrm{Cl}$ interactions are significantly weakened (Ag1-Cl2 2.7351(14) $\AA$ and $\mathrm{Ag}_{2}-\mathrm{Cl}_{1}$ $2.7350(14) \AA$ ). Compared with the lighter copper analogue, the structural parameters point towards an enhanced degree of halide transfer and incipient rearrangement of the core structure obviously caused by the larger coinage metal ion. However, in the light of metallophilic dispersion interactions especially observed for $\mathrm{d}^{10}$-metal ions, they are neither present in 5 nor in 6 ( $\mathrm{Ag}_{1}-\mathrm{Ag}_{2}$ 4.0655(9) $\AA$ ). Consequently, we aimed to synthesize the corresponding gold complex in order to follow the structural trends encountered so far.
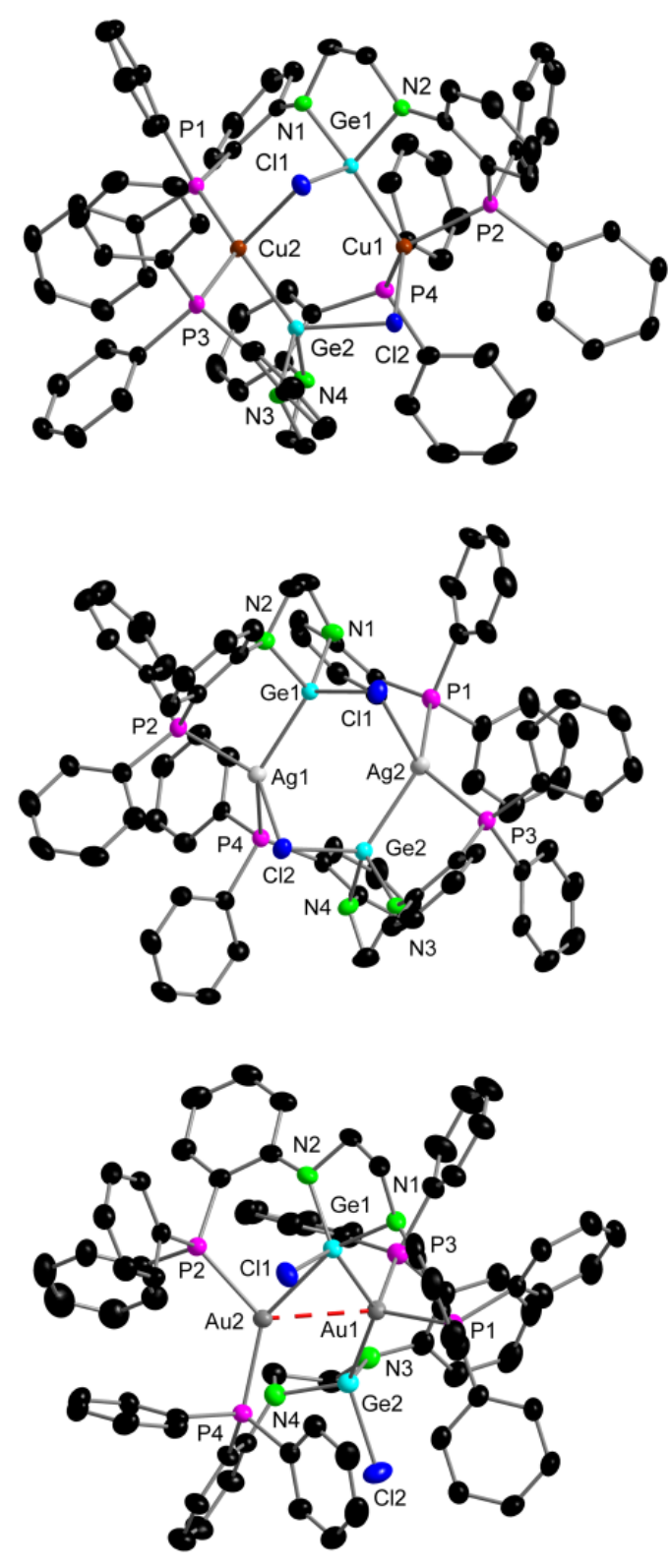

Figure 3. Molecular structures of the $[(\mathrm{PNNP}) \mathrm{Ge}]$ coinage metal complex $5(\mathrm{Cu}$, top), 6 (Ag, middle) and $7(\mathrm{Au}$, bottom) in the solid state. The thermal ellipsoids are set at a 50\% probability level. Solvent molecules and hydrogen atoms are not shown for clarity.

The reaction of $[(\mathrm{PNNP}) \mathrm{Ge}]$ with $\left[\left(\mathrm{Me}_{2} \mathrm{~S}\right) \mathrm{AuCl}\right]$ was conducted in benzene by simply dissolving both starting materials and letting the mixture stand overnight. Large single crystals of $\left[\{(\mathrm{PNNP}) \mathrm{GeCl}\}_{2} \mathrm{Au}_{2}\right] 7$ were obtained in almost quantitative yield overnight. The $\mathrm{X}$-ray structural 
analysis was hampered due to the high solvent content in the asymmetric unit ( 6 molecules of benzene) and rapid degradation of the crystals, but was possible under fast and cold conditions. In 7, no six-membered inorganic ring structure is found but instead, a triangular $\left\{\mathrm{GeAu}_{2}\right\}$ core forms the central structural motive. $\mathrm{A}\left\{\mathrm{Au}_{2}\right\}^{2+}$-dimer is bridged by a $\mu^{2}-\mathrm{Ge}$ with two $\sigma$-bound $\mathrm{Au}$ ions featuring similar bond lengths (Au1-Ge1 2.4975(5) ^̊, Au2-Ge1 2.6191(5) $\AA$ ). However, an ideal equilateral triangle is not formed since the interior angles slightly deviate from $60^{\circ}$ $\left(67.1^{\circ}, 54.4^{\circ}, 58.5^{\circ}\right)$. The Au1-Auz distance is remarkably short, 2.8293(2) A, which indicates a significant, albeit supported aurophilic interaction. Furthermore, Aur is uniquely bound to two Ge(II) sites (Au1-Gel 2.4975(5) $\AA$ and Au1-Ge2 2.4622(5) $\AA$ ) with even shorter bond lengths than $\mathrm{Ag}-\mathrm{Ge}$ bonds in $\mathbf{6}$.

The coordination sphere of Aur can be either described as a distorted seesaw or trigonal bipyramidal, which is unusual for $\mathrm{Au}(\mathrm{I})$ ions. Also, the $\mathrm{Au}-\mathrm{P}$ bond lengths differ and account for Au1-P1 2.3884(11) $\AA$ vs. Au1-P3 2.4855(12) $\AA$ A. In contrast, Auz features a slightly distorted trigonal planar coordination sphere with almost identical $\mathrm{Au}-\mathrm{P}$ distances of Au2-P2 2.3576(10) $\AA$ and Au2-P4 2.3451(11) Å. Compared to $\mathbf{5}$ and $\mathbf{6}$, full halide transfer from $\mathrm{Au}$ to $\mathrm{Ge}$ occurred and no $\mathrm{Au}-\mathrm{Cl}$ interactions are observed.
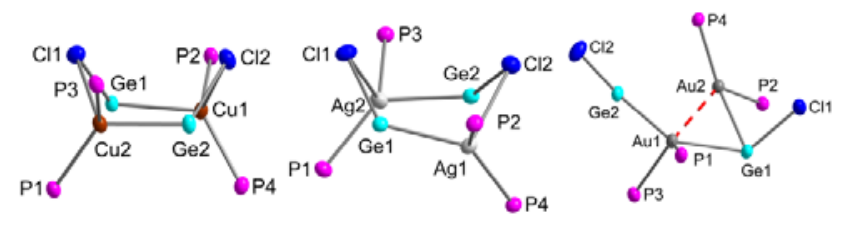

Figure 4. Core structures of $\mathbf{5}, \mathbf{6}$, and 7 illustrating the collapse of the rigid boat-type conformation (left) from $\mathrm{Cu}$ to $\mathrm{Au}$.

Thus, the rigid cyclic $\{\mathrm{GeMCl}\}$ substructure gradually collapses upon exchanging the coinage metal ion, which is likely caused by enhanced metallophilicity and enabled by the flexibility of the ligand framework (Figure 4). Complex 7 was investigated by NMR spectroscopic methods. In the ${ }^{31} \mathrm{P}\left\{{ }^{1} \mathrm{H}\right\}$ NMR spectrum, one broadened resonance is observed at $17.6 \mathrm{ppm}$, which is shifted downfield compared to $\mathbf{1}(+38.7 \mathrm{ppm})$. The broadness is suggested to be caused by a fast ligand exchange with respect to the donor moieties and $\left\{\mathrm{Au}_{2}\right\}^{2+}$ in solution, leading to a median rhomboid $\left\{(\mathrm{GeCl})_{2} \mathrm{Au}_{2}\right\}$ structure.

Additionally, germylene $\mathbf{1}$ was also found to react with two equivalents of copper(I) chloride leading to a larger cluster agglomerate. As evidenced by ${ }^{3} \mathrm{P}\left\{{ }^{1} \mathrm{H}\right\}$ NMR spectroscopy, a freshly prepared reaction mixture of $\mathbf{1}$ and two equivalents of $\mathrm{CuCl}$ in thf leads to clean and quantitative conversion of $\mathbf{1}$ to form a new metal complex. Only one resonance is observed under such conditions, which is downfield shifted at $-7.5 \mathrm{ppm}$ compared with the germylene ligand. The reaction product directly crystallizes from the mother liquor and, after diffraction experiments, was found to be the polynuclear complex $\left[\{(\mathrm{PNNP}) \mathrm{GeCl}\}\left\{\mathrm{Cu}_{2}\right\} \mathrm{Cl}\right]\left[\{(\mathrm{PNNP}) \mathrm{Ge}(\mathrm{thf})\} \mathrm{Cu}_{2}(\mathrm{Cl})_{2}\right]$ 8
Scheme 4. Synthesis of the polynuclear copper(I) compound 8.

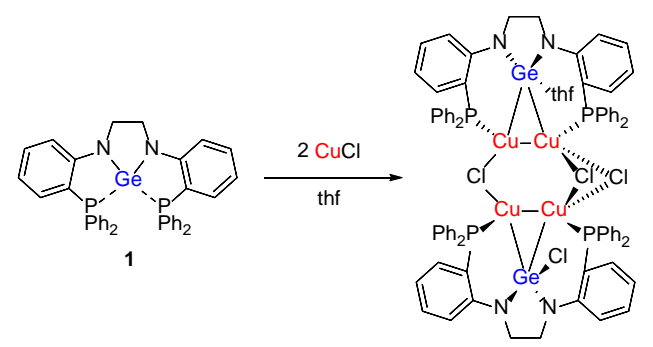

The analysis of the crystal structure revealed a formally dimeric structure, in which each of two germylene substituents coordinate to a $\left\{\mathrm{Cu}_{2}\right\}^{2+}$-moiety via $\mu^{2}$-Ge. The two $\left\{\mathrm{Cu}_{2}\right\}^{2+}$-units are additionally coordinated by two phosphines of the same ligand backbone, whereas the two $[(\mathrm{PNNP}) \mathrm{Ge}]$ ligands are inequivalent.

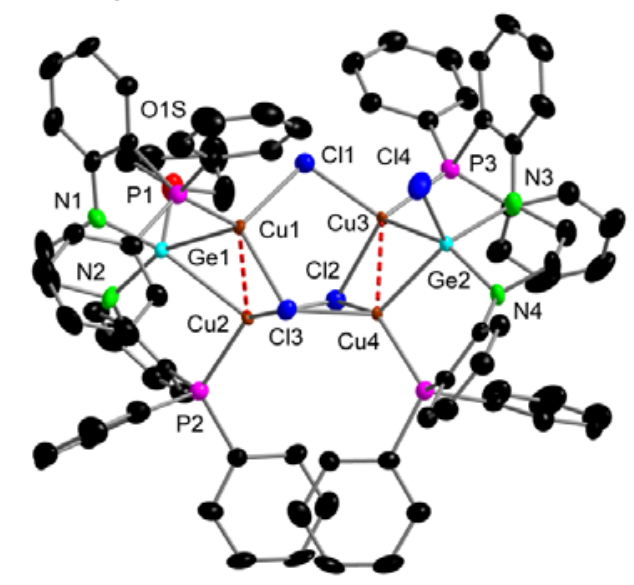

Figure 5. Molecular structure of $\mathbf{8}$ in the solid state. The thermal ellipsoids are set at a 50\% probability level. Solvent molecules and hydrogen atoms are not shown for clarity.

One germanium binds to a chloride ion, and the other one is coordinated by thf instead of a halide ion. Both fragments are linked together by three bridging $\mathrm{Cl}^{-}$ions. For the $\left\{\mathrm{GeCu}_{2}\right\}$ units, almost ideal equilateral triangular structures are found as all interior angles are close to $60^{\circ}$. $\mathrm{Cu}-\mathrm{Ge}$ bond lengths $(2.4326(14)-2.5487(15) \AA)$ are naturally longer compared with those in $\mathbf{5}$, and very short $\mathrm{Cu}-$ $\mathrm{Cu}$ distances of 2.519(2) $\AA$ (Cu1-Cuz) and 2.499(2) $\AA$ ) are realized here. The copper(I) distances are well below their sum of Van der Waals radii (2.8 $\AA$ ) and comparable to e.g. polynuclear copper(I) phosphine or amidinate compounds..$^{50-51}$ Consequently, the phosphine-functionalized germylene is also able to support the formation of larger metal agglomerates, thus underpinning its versatility.

In view of the results obtained with the germylene, we aimed to investigate the coordination behavior of 2 . Unfortunately, reactions of the corresponding stannylene 2 with coinage metal halides were less successful. Upon conversion with $\mathrm{CuCl}$ and $\left[\mathrm{AuCl}\left(\mathrm{SMe}_{2}\right)\right]$, visible decomposition and the formation of product mixtures accompanied by the extrusion of tin from the ligand scaffold was observed. Hence, we switched to halide-free metal pre(Scheme 4 and Figure 5). 
cursors and treated 2 with $\left[\mathrm{Pt}\left(\mathrm{C}_{2} \mathrm{H}_{4}\right)\left(\mathrm{PPh}_{3}\right)_{2}\right]$ (Scheme 5). Immediately after adding the platinum source, a dark red reaction mixture was obtained, from which the product precipitated as microcrystalline and insoluble red solid. Single crystal X-ray analysis revealed a mononuclear complex [\{(PNNP)Sn\}Pt $\left.\left(\mathrm{PPh}_{3}\right)\right]$ 9, in which the platinum atom is fully encapsulated by the pincer-type stannylene ligand. The distorted tetrahedral coordination sphere of $\mathrm{Pt}$ is completed by one $\mathrm{PPh}_{3}$ ligand (Figure 6).

In 9, the Pt1-Snı distances accounts for 2.5914(4) $\AA$, which is consistent with Pt-Sn distances of stannylene complexes reported by Hahn and coworkers..$^{22}$ Consequently, the (PNNP)E ligand scaffold is also able to act as a pincer ligand leading to simple and mononuclear complexes.

\section{Scheme 5. Synthesis of $\left[\{(\mathrm{PNNP}) \operatorname{Sn}\} \mathrm{Pt}\left(\mathrm{PPh}_{3}\right)\right] 9$.}
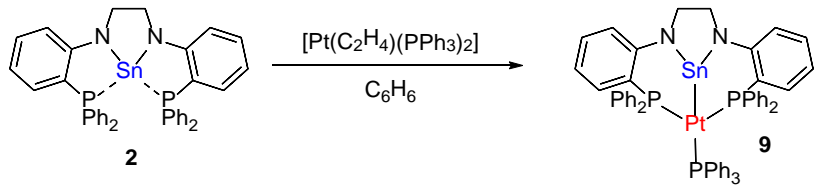

For 9, unfortunately, solution-based studies were prevented by its insolubility in common organic solvents. In contrast, decomposition is observed in halogenated solvents such as dichloromethane, and the decomposition product [(PNNP)Pt] (1o, see SI for structural details) appears as yellow crystalline product. Obviously, the formation of tin halides is highly favored in the presence of halide sources. CP-MAS NMR experiments were conducted (see SI for details). As in the crystal structure of $\mathbf{9}$ all the phosphorus atoms in the molecule are inequivalent and therefore give three separate peaks in the ${ }^{31} \mathrm{P} \mathrm{spec}$ trum, the phosphorus trans to tin is a singlet at $44.5 \mathrm{ppm}$ with ${ }^{195} \mathrm{Pt}$ satellites. The other two phosphorus resonances couple to each other and appear as doublets with associated ${ }^{195} \mathrm{Pt}$ satellites. No tin satellites are observed and the ${ }^{119} \mathrm{Sn}$ spectrum has one resonance at $132.6 \mathrm{ppm}$, but neither ${ }^{31} \mathrm{P}$ nor ${ }^{195} \mathrm{Pt}$ coupling could be resolved.

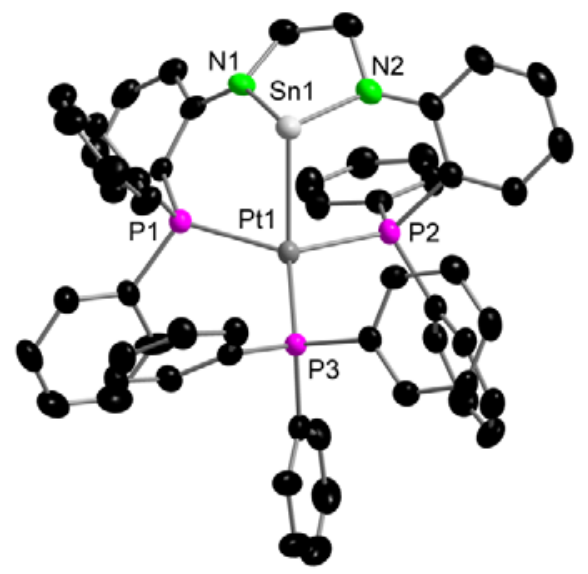

Figure 6. Molecular structure of $\left[\{(\mathrm{PNNP}) \mathrm{Sn}\} \mathrm{Pt}\left(\mathrm{PPh}_{3}\right)\right] \mathbf{9}$ in the solid state. The thermal ellipsoids are set at a $50 \%$ probability level. Solvent molecules and hydrogen atoms are not shown for clarity.

\section{CONCLUSION}

In summary, we synthesized two novel PEP ligands $(\mathrm{E}=$ $\mathrm{Ge}, \mathrm{Sn})$, which are readily accessible and persistently stable under an inert atmosphere. Both ligands exhibit divalent Ge or Sn donor sites and are best described as phosphine-functionalized heavier carbene analogues with strong E-P donor-acceptor interactions. However, they can also be seen as $\mathrm{P}-\mathrm{Ge}(\mathrm{II}) / \mathrm{Sn}$ (II) Lewis Pairs, which might find application in small molecule activation. The versatility of the framework was illustrated by their reactivity towards main group and transition metal compounds. Thereby, the ligand scaffold proved to be remarkably flexible and allowed for the isolation of structurally different compounds, dominantly influenced by the coordinated metals, under otherwise identical conditions. The ligands undergo insertion reactions into $\mathrm{M}-\mathrm{Cl}$ bonds $(\mathrm{M}=\mathrm{Cu}, \mathrm{Ag}, \mathrm{Au})$ and for $\mathrm{ECl}_{2}(\mathrm{E}=\mathrm{Ge}, \mathrm{Sn})$, act as either pincer-type or open-chain ligands with two bidentate donor sites. Since transition metal complexes are readily accessible from [(PNNP)E], they may find potential use in homogeneous catalysis.

\section{EXPERIMENTAL SECTION}

All general experimental methods and characterization data, including single crystal X-ray data, may be found in the Supporting Information.

Synthesis of [(PNNP)Ge] (1). PNHNHP (400 mg, o.68 mmol, 1.oo eq.), $\left[\mathrm{GeCl}_{2}\right.$ (dioxane)] (16o mg, $0.68 \mathrm{mmol}, 1.00$ eq.) and potassium bis(trimethylsilyl)amide $(275 \mathrm{mg}, 1.38$ mmol, 2.02 eq.) were weighted in a Schlenk tube inside the glovebox. THF (10 $\mathrm{mL}$ ) was added using a syringe and the resulting mixture was stirred at $60^{\circ} \mathrm{C}$ overnight. Subsequently, the reaction mixture was filtered with a Teflon cannula wrapped with a glass microfiber filter (Whatman ${ }^{\mathrm{TM}}$ ). A clear yellow solution was obtained, which was then dried under vacuum. The residue was dissolved in benzene (approx. 8 $\mathrm{mL}$ ) and carefully layered with $n$-pentane (approx. $50 \mathrm{~mL}$ ). Large yellow crystals were obtained after two days, which were separated from the mother liquor by decantation and dried under high vacuum. The crystals can be quickly washed with small amounts of benzene to remove surface impurities if necessary. Yield: $280 \mathrm{mg}$ (single crystals, $63 \%$ ). ${ }^{1} \mathrm{H}$ NMR $\left(\mathrm{C}_{6} \mathrm{D}_{6}, 400.30 \mathrm{MHz}\right): \delta[\mathrm{ppm}]=3.59\left(\mathrm{~s},{ }_{4} \mathrm{H}, \mathrm{CH}_{2}\right)$, $6.65\left(\mathrm{td}, 3 \mathrm{~J}_{\mathrm{H}-\mathrm{H}}=7.4 \mathrm{~Hz},{ }^{4} J_{\mathrm{H}-\mathrm{H}}=1.1 \mathrm{~Hz}, 2 \mathrm{H}, \mathrm{CH}\right), 6.87-7.02(\mathrm{~m}$, $14 \mathrm{H}, \mathrm{CH}), 7.24\left(\mathrm{ddd}, 3 J_{\mathrm{H}-\mathrm{H}}=8.6 \mathrm{~Hz}, 3 J_{\mathrm{H}-\mathrm{H}}=7.1 \mathrm{~Hz},{ }^{4} J_{\mathrm{H}-\mathrm{H}}=1.7\right.$ $\mathrm{Hz}, 2 \mathrm{H}, \mathrm{CH}), 7.31-7.44(\mathrm{~m}, 10 \mathrm{H}, \mathrm{CH}) .{ }^{13} \mathrm{C}\left\{{ }^{1} \mathrm{H}\right\}$ NMR $\left(\mathrm{C}_{6} \mathrm{D}_{6}\right.$, 100.67 MHz): $\delta[\mathrm{ppm}]=51.6\left(\mathrm{CH}_{2}\right), 117.6\left(\mathrm{t},{ }^{4} \mathrm{~J}_{\mathrm{P}-\mathrm{C}}=2.5 \mathrm{~Hz}\right.$, $\mathrm{CH}), 118.3(\mathrm{CH}), 120.8\left(\mathrm{t},{ }_{1} \mathrm{~J}_{\mathrm{P}-\mathrm{C}}=9.5 \mathrm{~Hz}, C_{q}\right), 128.7\left(\mathrm{t},{ }^{3} J_{\mathrm{P}-\mathrm{C}}=3.7\right.$ $\mathrm{Hz}, \mathrm{CH}), 128.8(\mathrm{CH}), 131.9(\mathrm{CH}), 133.6\left(\mathrm{t},{ }^{2} \mathrm{~J}_{\mathrm{P}-\mathrm{C}}=8.0 \mathrm{~Hz}, \mathrm{CH}\right)$, ${ }_{136.3}(\mathrm{CH}), 136.8\left(C_{q}\right), 158.5\left(\mathrm{t},{ }^{2} \mathrm{~J}_{\mathrm{P}-\mathrm{C}}=12.2 \mathrm{~Hz}, C_{q}\right) .{ }^{3} \mathrm{P}\left\{{ }^{1} \mathrm{H}\right\}$ $\operatorname{NMR}\left(\mathrm{C}_{6} \mathrm{D}_{6}, 162.04 \mathrm{MHz}\right): \delta[\mathrm{ppm}]=-21.1$. IR $(\mathrm{ATR}): \mathrm{v}\left(\mathrm{cm}^{-1}\right)=$ $2962(\mathrm{w}), 2925$ (w), $2872(\mathrm{w}), 1654$ (w), 1578 (m), 1560 (w), $1478(\mathrm{w}), 1462(\mathrm{~m}), 1452(\mathrm{~s}), 1434(\mathrm{~s}), 1364(\mathrm{w}), 1297(\mathrm{~s}), 1235$ $(\mathrm{w}), 1210(\mathrm{w}), 1181(\mathrm{w}), 1161(\mathrm{w}), 1136(\mathrm{w}), 1088(\mathrm{~m}), 1056(\mathrm{w})$, $1039(w), 1027(w), 998(w), 968(w), 935(w), 871(w), 821(m)$, 760 (vs), 693 (vs), 684 (vs), 668 (m), 653 (w), 636 (w). Raman (solid state, sealed ampule): $v\left(\mathrm{~cm}^{-1}\right)=1582,1301,1157,1086$, 1027, 696, 631, 522, 470, 423, 241. Elemental analysis calcd (\%) for $\left[\mathrm{C}_{38} \mathrm{H}_{32} \mathrm{GeN}_{2} \mathrm{P}_{2}\right](651.27 \mathrm{~g} / \mathrm{mol})$ : $\mathrm{C}$ 70.08, $\mathrm{H}$ 4.95, N 4.30; found $\mathrm{C}_{70.97} \mathrm{H}_{5.13}, \mathrm{~N} 3.96$. 
Synthesis of [(PNNP)Sn] (2). PNHNHP (400 mg, 0.68 mmol, 1.00 eq.), anhydrous $\mathrm{SnCl}_{2}$ (131 $\mathrm{mg}, 0.68 \mathrm{mmol}, 1.00$ eq.) and potassium bis(trimethylsilyl)amide $(275 \mathrm{mg}, 1.38$ mmol, 2.02 eq.) were weighted in a Schlenk tube inside the glovebox. THF $(20 \mathrm{~mL})$ was added using a syringe and the resulting mixture was stirred at $60^{\circ} \mathrm{C}$ overnight. Subsequently, the reaction mixture was filtered with a Teflon cannula wrapped with a glass microfiber filter (Whatman ${ }^{\mathrm{TM}}$ ). A clear yellow solution was obtained, which was then dried under vacuum. The residue was dissolved in benzene (approx. 10 $\mathrm{mL}$ ) and carefully layered with $n$-hexane (approx. $50 \mathrm{~mL}$ ). Large yellow crystals were obtained within one week, which were separated from the mother liquor by decantation and dried under high vacuum. The crystals can be quickly washed with small amounts of benzene to remove surface impurities if necessary. Yield: $270 \mathrm{mg}$ (single crystals, $57 \%$ ). ${ }^{1} \mathrm{H}$ NMR (thf- $\left.d_{8}, 400.30 \mathrm{MHz}\right): \delta[\mathrm{ppm}]=3.49\left(\mathrm{~s}, 4 \mathrm{H}, \mathrm{CH}_{2}\right)$, $6.32\left(\mathrm{t}, 3 \mathrm{~J}_{\mathrm{H}-\mathrm{H}}=7.3 \mathrm{~Hz}, 2 \mathrm{H}, \mathrm{CH}\right), 6.61-6.71(\mathrm{~m}, 2 \mathrm{H}, \mathrm{CH}), 6.88-$ $6.98(\mathrm{~m}, 2 \mathrm{H}, \mathrm{CH}), 7.15\left(\mathrm{t}, 3 \mathrm{~J}_{\mathrm{H}-\mathrm{H}}=7.9 \mathrm{~Hz}, 2 \mathrm{H}, \mathrm{CH}\right), 7.19-7.37$ $(\mathrm{m}, 2 \mathrm{OH}, \mathrm{CH}) .{ }^{13} \mathrm{C}\left\{{ }^{1} \mathrm{H}\right\}$ NMR (thf- $\left.d_{8}, 100.67 \mathrm{MHz}\right): \delta[\mathrm{ppm}]=$ 49.0 $\left(\mathrm{CH}_{2}\right)$, $114.2(\mathrm{CH})$, $114.5(\mathrm{CH}), 129.2\left(C_{q}\right)$, $129.6(\mathrm{CH}), 130.3$ $(\mathrm{CH}), 133.3(\mathrm{CH}), 134.2(\mathrm{CH}), 134.8\left(C_{q}\right), 136.1(\mathrm{CH}), 161.8\left(C_{q}\right)$. ${ }^{31} \mathrm{P}\left\{{ }^{1} \mathrm{H}\right\}$ NMR (thf- $\left.d_{8}, 162.04 \mathrm{MHz}\right): \delta[\mathrm{ppm}]=-20.3$, Snsatellites $\left(\mathrm{d},{ }^{1} J_{\mathrm{P}-117 \mathrm{Sn}}=1295 \mathrm{~Hz}\right)$ and $\left(\mathrm{d},{ }^{1} J_{\mathrm{P}-119 \mathrm{Sn}}=1355 \mathrm{~Hz}\right)$. ${ }^{119} \mathrm{Sn}\left\{{ }^{1} \mathrm{H}\right\}$ NMR (thf- $\left.d_{8}, 149.5 \mathrm{MHz}\right): \delta[\mathrm{ppm}]=-269.8\left(\mathrm{t},{ }^{1}{ }_{\mathrm{P}-\mathrm{Sn}}\right.$ $=1348 \mathrm{~Hz})$. IR (Nujol): v( $\left.\mathrm{cm}^{-1}\right)=1577(\mathrm{~m}), 1539(\mathrm{w}), 1459(\mathrm{~s})$, $1434(\mathrm{~m}), 1377(\mathrm{~m}), 1310(\mathrm{~m}), 1278(\mathrm{w}), 1261(\mathrm{w}), 1211(\mathrm{w}), 1158$ (w), $1134(w), 1032(w), 953(w), 929(w), 859(w), 807(w), 736$ (m), $723(\mathrm{w}), 682(\mathrm{~m})$. Raman (solid state, sealed ampule): $v\left(\mathrm{~cm}^{-1}\right)=3046,1582,1327,1181,1157,1134,1092,1033,997,953$, 851, 618, 559, 436, 391, 332, 312, 276, 251, 228. Elemental analysis calcd (\%) for $\left[\mathrm{C}_{38} \mathrm{H}_{32} \mathrm{~N}_{2} \mathrm{P}_{2} \mathrm{Sn}\right](697.35 \mathrm{~g} / \mathrm{mol})$ : $\mathrm{C} 65.45, \mathrm{H}$ 4.63, N 4.02; found C 66.12, H 4.82, N 3.57.

Synthesis of $\left[(\mathrm{PNNP})(\mathrm{GeCl})_{2}\right](3)$. [(PNNP) Ge] $(37 \mathrm{mg}$, $0.05 \mathrm{mmol}$, 1.0o eq.) and $\left[\mathrm{GeCl}_{2}\right.$ (dioxane) $](13.2 \mathrm{mg}, 0.05$ mmol, 1.oo eq.) are added to a Schlenk tube, dissolved in benzene $(5 \mathrm{~mL})$ and stirred until a clear yellowish solution is obtained. Upon concentration, the product precipitates as yellowish powder and is recrystallized from hot benzene to obtain colorless crystals. The crystals are separated from the mother liquor by decantation and dried under vacuum. Yield: $37 \mathrm{mg}(83 \%)$. ${ }^{1} \mathrm{H}$ NMR (pyridine- $d_{5}, 400.3 \mathrm{MHz}$ ): $\delta$ $[\mathrm{ppm}]=3.49\left(\mathrm{bs}, 4 \mathrm{H}, \mathrm{CH}_{2}\right), 6.72-6.85(\mathrm{~m}, 4 \mathrm{H}, \mathrm{CH}), 7.25-7.55$ $(\mathrm{m}, 24 \mathrm{H}, \mathrm{CH}) .{ }^{13} \mathrm{C}\left\{{ }^{1} \mathrm{H}\right\}$ NMR (pyridine- $\left.d_{5}, 100.67 \mathrm{MHz}\right): \delta$ [ppm] $=51.5\left(\mathrm{CH}_{2}\right), 115.4,117.5,121.9,128.2$ (overlapping), 128.8 (overlapping), 131.2, 133.5, 137.1, 138.9, 157.9 (NC). Note: All resonances broad. ${ }^{3} \mathrm{P}\left\{{ }^{1} \mathrm{H}\right\}$ NMR (pyridine- $d_{5}, 162.04 \mathrm{MHz}$ ): $\delta$ [ppm] $=-21.6$. IR (Nujol): $v\left(\mathrm{~cm}^{-1}\right)=1577(\mathrm{w}), 1334(\mathrm{w}), 1285$ (w), 1261 (vw), 1218 (vw), 1167 (vw), 1098 (vw), 1044 (vw), 1035 (vw), $857(\mathrm{vw}), 802(\mathrm{vw}), 746(\mathrm{w}), 721(\mathrm{w}), 688(\mathrm{w})$. Elemental analysis calcd (\%) for $\left[\mathrm{C}_{38} \mathrm{H}_{32} \mathrm{Cl}_{2} \mathrm{Ge}_{2} \mathrm{~N}_{2} \mathrm{P}_{2}\right](794.8 \mathrm{o} \mathrm{g} / \mathrm{mol})$ : $\mathrm{C}$ 57.43, H 4.06, N 3.52; found C 57.68, H 4.28, N 3.08.

Synthesis of $\left[(\mathrm{PNNP})(\mathrm{SnCl})_{2}\right](4)$. [(PNNP)Sn] $30.8 \mathrm{mg}$, $0.04 \mathrm{mmol}$, 1.oo eq.) and $\mathrm{SnCl}_{2}(8.4 \mathrm{mg}$, $0.04 \mathrm{mmol}$, 1.00 eq.) are weighed into a Schlenk tube. Benzene $(5 \mathrm{~mL})$ and thf $(1-2$ $\mathrm{mL}$ ) are added and the mixture is stirred until a clear solution is obtained. Upon concentration, the product precipitates as yellowish powder and is recrystallized by heating. Colorless rod-like crystals are separated from the mother liquor by decantation and dried under vacuum. The complex partially decomposes upon attempts to redissolve it e.g. for NMR measurements. Yield: $28 \mathrm{mg}$ (79\%, single crystals). ${ }^{1} \mathrm{H}$
NMR (pyridine- $\left.d_{5}, 400.30 \mathrm{MHz}\right): \delta[\mathrm{ppm}]=3.43(\mathrm{bs}, 4 \mathrm{H}$, $\left.\mathrm{CH}_{2}\right), 6.57^{-6.64}(\mathrm{~m}, 4 \mathrm{H}, \mathrm{CH}), 7.24^{-7} .34(\mathrm{~m}, 16 \mathrm{H}, \mathrm{CH}), 7.39^{-}$ $7.44(\mathrm{~m}, 8 \mathrm{H}, \mathrm{CH}) .{ }^{13} \mathrm{C}\left\{{ }^{1} \mathrm{H}\right\}$ NMR: Due to the low solubility, no meaningful spectrum could be recorded. ${ }^{3} \mathrm{P}\left\{{ }^{1} \mathrm{H}\right\}$ NMR (pyridine- $\left.d_{5}, 162.04 \mathrm{MHz}\right): \delta[\mathrm{ppm}]=-19.8$, Sn-satellites $\left(\mathrm{d},{ }^{1}{ }_{\mathrm{P}-\mathrm{Sn}}\right.$ $=405 \mathrm{~Hz}),-22.7$. IR (Nujol): $v\left(\mathrm{~cm}^{-1}\right)=1578(\mathrm{w}), 1302(\mathrm{w}), 1233$ (w), 1260 (w), $1206(v w), 1154(w), 1096(v w), 1039(v w), 1024$ (vw), $740(\mathrm{w}), 721(\mathrm{w}), 678(\mathrm{w})$. Elemental analysis calcd (\%) for $\left[\mathrm{C}_{38} \mathrm{H}_{32} \mathrm{Cl}_{2} \mathrm{~N}_{2} \mathrm{P}_{2} \mathrm{Sn}_{2}\right](886.96 \mathrm{~g} / \mathrm{mol})$ : $\mathrm{C}$ 51.46, H 3.64, N 3.16; found $\mathrm{C}_{51.18}, \mathrm{H}$ 3.72, N 2.38.

Synthesis of $[(\mathrm{PNNP}) \mathrm{GeCu}(\boldsymbol{\mu}-\mathrm{Cl})]_{2}$ (5). [(PNNP)Ge] ${ }_{56}$ $\mathrm{mg}$, $0.08 \mathrm{mmol}, 1.00$ eq.) and $\mathrm{CuCl}(8.6 \mathrm{mg}, 0.08 \mathrm{mmol}, 1.00$ eq.) were weighed in a Schlenk tube and cooled to $-78^{\circ} \mathrm{C}$. Toluene $(5 \mathrm{~mL})$ was added and the suspension was stirred at low temperature and slowly brought to room temperature ( 3 hours). Subsequently, thf ( $3 \mathrm{~mL}$ ) was added and the yellow solution was stirred overnight. The yellow solution was then concentrated until a colorless precipitate formed $(\sim 3 \mathrm{~mL})$. The suspension was gently heated until a clear and almost colorless solution formed and left standing for 2 days. Colorless crystals were obtained, isolated from the mother liquor by decantation and dried under vacuum. Yield: $46 \mathrm{mg}$ (77\%, single crystals). ${ }^{1} \mathrm{H}$ NMR $\left(\mathrm{C}_{6} \mathrm{D}_{6}, 400.3 \mathrm{MHz}\right): \delta[\mathrm{ppm}]=2.83$ $\left(\mathrm{dd}, 3 J_{\mathrm{H}-\mathrm{H}}=8.4 \mathrm{~Hz}, 3 J_{\mathrm{H}-\mathrm{H}}=4.4 \mathrm{~Hz}, 2 \mathrm{H}, \mathrm{CH}_{2}\right), 3.02\left(\mathrm{dd}, 3 J_{\mathrm{H}-\mathrm{H}}=\right.$ $9.5 \mathrm{~Hz}, 3 \mathrm{~J}_{\mathrm{H}-\mathrm{H}}=4.6 \mathrm{~Hz}, 2 \mathrm{H}, \mathrm{CH}_{2}$ ), 3.60 (overlapping, $2 \mathrm{H}, \mathrm{CH}_{2}$ ), 3.68-3.76 (m, $\left.\left.2 \mathrm{H}, \mathrm{CH}_{2}\right), 6.38(\mathrm{t}, 3)_{\mathrm{H}-\mathrm{H}}=8.2 \mathrm{~Hz}, 2 \mathrm{H}, \mathrm{CH}\right), 6.42-$ 6.50 (m, $4 \mathrm{H}, \mathrm{CH}), 6.65-6.74(\mathrm{~m}, 8 \mathrm{H}, \mathrm{CH}), 6.75-6.90(\mathrm{~m}, 12 \mathrm{H}$, $\mathrm{CH}$ ), 6.90-7.12 (overlapping, $22 \mathrm{H}, \mathrm{CH}), 7.44(\mathrm{dd}, 3)_{\mathrm{H}-\mathrm{H}}=11.2$ $\left.\mathrm{Hz},{ }^{3} \mathrm{H}_{\mathrm{H}-\mathrm{H}}=7.5 \mathrm{~Hz}, 4 \mathrm{H}, \mathrm{CH}\right), 7.72(\mathrm{bs}, 4 \mathrm{H}, \mathrm{CH}) .{ }^{13} \mathrm{C}\left\{{ }^{1} \mathrm{H}\right\}$ NMR: Due to the low solubility, no meaningful spectrum could be recorded. ${ }^{31} \mathrm{P}\left\{{ }^{1} \mathrm{H}\right\}$ NMR $\left(\mathrm{C}_{6} \mathrm{D}_{6}, 162.04 \mathrm{MHz}\right): \delta[\mathrm{ppm}]=-0.6$ (bs), 9.5 (bs). IR (ATR): $v\left(\mathrm{~cm}^{-1}\right)=1577(\mathrm{~m}), 1463(\mathrm{~m}), 1449$ (w), $1432(\mathrm{~s}), 1281(\mathrm{~s}), 1248(\mathrm{~m}), 1137(\mathrm{w}), 1094(\mathrm{w}), 1063(\mathrm{~m})$, 1027 (w), 871 (w), 832 (m), 755 (s), 743 (s), $730(\mathrm{~m}), 693$ (s), $678(\mathrm{w}), 645(\mathrm{w}), 633$ (w). Elemental analysis calcd (\%) for $\left[\mathrm{C}_{76} \mathrm{H}_{64} \mathrm{Cl}_{2} \mathrm{Cu}_{2} \mathrm{Ge}_{2} \mathrm{~N}_{4} \mathrm{P}_{4} \cdot \mathrm{C}_{7} \mathrm{H}_{8}\right](1500.52 \mathrm{~g} / \mathrm{mol}): \mathrm{C} 62.59, \mathrm{H} 4.56$, $\mathrm{N}$ 3.52; found $\mathrm{C}$ 62.52, $\mathrm{H}$ 4.78, $\mathrm{N}$ 3.00.

Synthesis of $[(\mathrm{PNNP}) \mathrm{AgCu}(\boldsymbol{\mu}-\mathrm{Cl})]_{2}(6) .[(\mathrm{PNNP}) \mathrm{Ge}](50$ $\mathrm{mg}$, $0.07 \mathrm{mmol}$, 1.oo eq.) and $\mathrm{AgCl}(11 \mathrm{mg}, 0.07 \mathrm{mmol}$, 1.00 eq.) were weighed in a Schlenk tube and cooled to $-78^{\circ} \mathrm{C}$. Toluene $(5 \mathrm{~mL})$ was added and the suspension was stirred at low temperature and slowly brought to room temperature ( 3 hours). Subsequently, thf ( $3 \mathrm{~mL}$ ) was added and the suspension was stirred overnight. The light yellow mixture was then concentrated until a colorless precipitate formed $(\sim 3$ $\mathrm{mL}$ ). The suspension was gently heated until a clear and almost colorless solution formed and left standing for 2 days. Colorless crystals were obtained, isolated from the mother liquor by decantation and dried under vacuum. Yield: $39 \mathrm{mg}$ (70 \%, single crystals). ${ }^{1} \mathrm{H}$ NMR (thf- $d_{8}, 400.30 \mathrm{MHz}$ ): $\delta$ [ppm] $=2.71\left(\mathrm{dd},{ }^{3} J_{\mathrm{H}-\mathrm{H}}=8.5 \mathrm{~Hz},{ }^{3} J_{\mathrm{H}-\mathrm{H}}=4.8 \mathrm{~Hz}, 2 \mathrm{H}, \mathrm{CH}_{2}\right), 2.84(\mathrm{dd}$, $\left.3 J_{\mathrm{H}-\mathrm{H}}=9.9 \mathrm{~Hz}, 3 J_{\mathrm{H}-\mathrm{H}}=4.9 \mathrm{~Hz}, 2 \mathrm{H}, \mathrm{CH}_{2}\right), 3.08-3.16(\mathrm{~m}, 2 \mathrm{H}$, $\mathrm{CH}_{2}$ ), 3.48-3.55 (overlapping, $\left.2 \mathrm{H}, \mathrm{CH}_{2}\right), 6.27\left(\mathrm{t}, 3 \mathrm{~J}_{\mathrm{H}-\mathrm{H}}=8.4\right.$ $\mathrm{Hz}, 2 \mathrm{H}, \mathrm{CH}), 6.41\left(\mathrm{t}, 3 \mathrm{~J}_{\mathrm{H}-\mathrm{H}}=8.1 \mathrm{~Hz}, 2 \mathrm{H}, \mathrm{CH}\right), 6.46-6.55(\mathrm{~m}$, $8 \mathrm{H}, \mathrm{CH}), 6.70-6.90(\mathrm{~m}, 8 \mathrm{H}, \mathrm{CH})$, 7.02-7.25 (m, overlapping, $18 \mathrm{H}, \mathrm{CH}), 7.28-7.47(\mathrm{~m}, 16 \mathrm{H}, \mathrm{CH}), 7.55$ (bs, $\left.2 \mathrm{H}, \mathrm{CH}) .{ }^{13} \mathrm{C}^{1}{ }^{1} \mathrm{H}\right\}$ NMR: Due to the low solubility, no meaningful spectrum could be recorded. ${ }^{11} \mathrm{P}\left\{{ }^{1} \mathrm{H}\right\}$ NMR (thf- $d_{8}, 162.04 \mathrm{MHz}$ ): $\delta$ $[\mathrm{ppm}]=3.7\left(\mathrm{~d},{ }^{1} \mathrm{~J}_{\mathrm{Ag}-\mathrm{P}}=248 \mathrm{~Hz}\right) 13.4\left(\mathrm{~d},{ }^{1} J_{\mathrm{Ag}-\mathrm{P}}=419 \mathrm{~Hz}\right) . \mathrm{IR}$ (Nujol): $v\left(\mathrm{~cm}^{-1}\right)=2725(\mathrm{w}), 1574(\mathrm{w}), 1302(\mathrm{w}), 1277(\mathrm{w}), 1260$ $(w), 1155(w), 1095(w), 1026(w), 800(w), 722(w), 692(w)$. Raman (solid state, sealed ampule): $v\left(\mathrm{~cm}^{-1}\right)=3053,1581,1387$, 
1296, 1154, 1093, 1040, 1027, 998, 853, 784, 700, 630, 616, 453, 397, 253, 227. Elemental analysis calcd (\%) for $\left[\mathrm{C}_{76} \mathrm{H}_{64} \mathrm{Ag}_{2} \mathrm{Cl}_{2} \mathrm{Ge}_{2} \mathrm{~N}_{4} \mathrm{P}_{4} \times \mathrm{C}_{7} \mathrm{H}_{8}\right](1589.18 \mathrm{~g} / \mathrm{mol}): \mathrm{C}_{59.29}, \mathrm{H}$ 4.32, N 3.33; found $\mathrm{C}_{58.71} \mathrm{H}_{3} .82, \mathrm{~N} 2.51$.

Synthesis of $\left[\left\{(\mathrm{PNNP}) \mathrm{GeCl}_{2} \mathrm{Au}_{2}\right](7)\right.$. [(PNNP)Ge] $(53 \mathrm{mg}$, $0.08 \mathrm{mmol}, 1.00$ eq. $)$ and $\left[\mathrm{AuCl}\left(\mathrm{SMe}_{2}\right)\right](24 \mathrm{mg}, 0.08 \mathrm{mmol}$, 1.00 eq.) were dissolved in $\mathrm{C}_{6} \mathrm{D}_{6}$ at room temperature and stirred for one hour. The resulting yellow solution was concentrated until incipient precipitation of the product occurred. The precipitate was redissolved by gentle heating $(50$ ${ }^{\circ} \mathrm{C}$ ) and left standing overnight. Colorless block-like crystals were obtained within hours, separated from the mother liquor by decantation and dried under vacuum. Yield: $62 \mathrm{mg}$ (single crystals, $87 \%)$. ${ }^{1} \mathrm{H}$ NMR $\left(\mathrm{C}_{6} \mathrm{D}_{6}, 400.30 \mathrm{MHz}\right): \delta[\mathrm{ppm}]$ $=2.86\left(\mathrm{bs}, 2 \mathrm{H}, \mathrm{CH}_{2}\right), 3.00\left(\mathrm{bs}, 2 \mathrm{H}, \mathrm{CH}_{2}\right), 3.67\left(\mathrm{bs}, 4 \mathrm{H}, \mathrm{CH}_{2}\right)$, $6.53\left(\mathrm{t}, 3 J_{\mathrm{H}-\mathrm{H}}=7.4 \mathrm{~Hz}, 2 \mathrm{H}, \mathrm{CH}\right), 6.61\left(\mathrm{t}, 3 \mathrm{~J}_{\mathrm{H}-\mathrm{H}}=7.5 \mathrm{~Hz}, 2 \mathrm{H}\right.$, $\mathrm{CH}), 6.78\left(\mathrm{t}, 33_{\mathrm{H}-\mathrm{H}}=7.6 \mathrm{~Hz}, 4 \mathrm{H}, \mathrm{CH}\right), 6.82-7.12(\mathrm{~m}, 38 \mathrm{H}, \mathrm{CH})$, 7.2-7.35 (m, 6H, CH), 7.55-7.71 (m, $4 \mathrm{H}, \mathrm{CH}) .{ }^{13 \mathrm{C}}\left\{{ }_{1} \mathrm{H}\right\}$ NMR $\left(\mathrm{C}_{6} \mathrm{D}_{6}, 125.8 \mathrm{MHz}\right): \delta[\mathrm{ppm}]=50.7\left(\mathrm{CH}_{2}\right), 118.7,119.7,120.6$, $127.5,128.6,128.8,129.4,130.3,131.8,131.9,132.7,132.9,134.0$, 134.2, 135.1, 136.5, 155.7, 158.0. ${ }^{31} \mathrm{P}\left\{{ }^{1} \mathrm{H}\right\} \quad \mathrm{NMR}\left(\mathrm{C}_{6} \mathrm{D}_{6}, 162.04\right.$ $\mathrm{MHz}): \delta[\mathrm{ppm}]=17.6(\mathrm{bs})$. IR (ATR): $\mathrm{v}\left(\mathrm{cm}^{-1}\right)=1578(\mathrm{~m}), 1560$ $(\mathrm{w}), 1478(\mathrm{w}), 1460(\mathrm{~m}), 1449(\mathrm{w}), 1433(\mathrm{~s}), 1284(\mathrm{~s}), 1243(\mathrm{~m})$, $1170(w), 932(w), 868(w), 842(w), 830(w), 810(w), 794(w)$, 741 (s), 692 (s), $672(\mathrm{w}), 664(\mathrm{w}), 638$ (m). Raman (solid state, sealed ampule): $v\left(\mathrm{~cm}^{-1}\right)=3053,2290,1583,1156,1092,1070$, 1027, 1026, 998, 943, 851, 696, 629, 574, 511, 452, 402, 383, 358, 262. Elemental analysis calcd (\%) for $\left[\mathrm{C}_{76} \mathrm{H}_{64} \mathrm{Au}_{2} \mathrm{Cl}_{2} \mathrm{Ge}_{2} \mathrm{~N}_{4} \mathrm{P}_{4}\right]$ (1767.36 g/mol): C 51.65, H 3.65, N 3.17; found C 52.34, H 3.88, N 2.75 .

Synthesis [\{(PNNP) $\left.\left.(\mathrm{GeCl}) \mathrm{Cu}_{2}\right\}\left\{(\mathrm{PNNP}) \mathrm{Ge}(\mathrm{thf}) \mathrm{Cu}_{2}(\mathrm{Cl})_{2}\right\}\right]$

[(PNNP)Ge] (50 mg, $0.07 \mathrm{mmol}, 1.00$ eq.) and $\mathrm{CuCl}(15.2 \mathrm{mg}$ $1.53 \mathrm{mmol}, 2.00$ eq.) were weighed in a Schlenk flask and thf ( $5 \mathrm{~mL})$ was added. The mixture was heated to reflux and until a clear orange solution was obtained. After concentration to 1-2 $\mathrm{mL}$, the product crystallizes within 2 weeks and was removed from the mother liquor by decantation. Yield: $25 \mathrm{mg}$ (41\%, single crystals). NMR spectra were recorded from a freshly prepared reaction solution. ${ }^{1} \mathrm{H}$ NMR (thf- $d_{8}$, 400.30 MHz): $\delta[\mathrm{ppm}]=2.93(\mathrm{bs}, 8 \mathrm{H}, \mathrm{CH} 2), 6.51\left(\mathrm{t}, 3 J_{\mathrm{H}-\mathrm{H}}=7.6\right.$ $\left.\mathrm{Hz},{ }_{4} \mathrm{H}, \mathrm{CH}\right), 6.67\left(\mathrm{t},{ }_{3} J_{\mathrm{H}-\mathrm{H}}=7.6 \mathrm{~Hz},{ }_{4} \mathrm{H}, \mathrm{CH}\right), 7.02-7.34(\mathrm{~m}$, $32 \mathrm{H}, \mathrm{CH}), 7.42-7.65(\mathrm{~m}, 8 \mathrm{H}, \mathrm{CH}) .{ }^{13} \mathrm{C}\left\{{ }^{1} \mathrm{H}\right\}$ NMR (thf- $d_{8}, 100.67$ $\mathrm{MHz}): \delta[\mathrm{ppm}]=25.9$ (thf), $54.2\left(\mathrm{CH}_{2}\right), 68.1$ (thf), 121.2 (bs), 122.8 (bs), $125.5\left(\mathrm{~d},{ }^{1} J_{\mathrm{P}-\mathrm{C}}=39.5 \mathrm{~Hz}\right), 129.33\left(\mathrm{~d},{ }^{3} J_{\mathrm{P}-\mathrm{C}}=9.1 \mathrm{~Hz}\right)$, 130.4 (bs), 131.6 (bs), 133.1 (bs), 134.07 (d, J $\left._{\mathrm{P}-\mathrm{C}}=32.1 \mathrm{~Hz}\right) 135.09$ $\left(\mathrm{d},{ }^{3} J_{\mathrm{P}-\mathrm{C}}=11.9 \mathrm{~Hz}\right), 156.8(\mathrm{NC}) .{ }^{31} \mathrm{P}\left\{{ }^{1} \mathrm{H}\right\} \mathrm{NMR}\left(\right.$ thf- $d_{8}, 162.04$ $\mathrm{MHz}): \delta[\mathrm{ppm}]=-7.5$ (bs). IR (Nujol): $\mathrm{v}\left(\mathrm{cm}^{-1}\right)=2725(\mathrm{w})$, $1578(w), 1303(w), 1260(w), 1155(w), 1095(w), 10126(w), 800$ $\mathrm{w}), 721(\mathrm{~m}), 692(\mathrm{w})$. Elemental analysis calcd (\%) for $\left[\mathrm{C}_{80} \mathrm{H}_{72} \mathrm{Cl}_{4} \mathrm{Cu}_{4} \mathrm{Ge}_{2} \mathrm{~N}_{4} \mathrm{OP}_{4}\right]$ (1770.62 g/mol): $\mathrm{C}_{54.27}, \mathrm{H} 4.10, \mathrm{~N}$ 3.16; found $\mathrm{C}_{54.39}, \mathrm{H} 4.35, \mathrm{~N}_{3} .14$.

Synthesis of [\{(PNNP)Sn\}Pt(PPh $\left.\left.{ }_{3}\right)\right]$ (9). [(PNNP)Sn] (24 $\mathrm{mg}$, $0.03 \mathrm{mmol}$, 1.00 eq.) was dissolved in benzene (1-2 $\mathrm{mL})$. A solution of $\left[\mathrm{Pt}\left(\mathrm{C}_{2} \mathrm{H}_{4}\right)\left(\mathrm{PPh}_{3}\right)_{2}\right](26 \mathrm{mg}, 0.03 \mathrm{mmol}$, 1.0o eq.) in benzene $(1 \mathrm{~mL})$ was added, which immediately led to a dark red solution and precipitation of the product. Small, dark red crystals formed within days, which were removed from the mother liquor by decantation and dried under vacuum. The product is insoluble in common organic solvents including pyridine and dichlorobenzene, and decomposes in $\mathrm{CH}_{2} \mathrm{Cl}_{2}$ or $\mathrm{CHCl}_{3}$ to form [(PNNP)Pt] (10, see SI). Yield: $22 \mathrm{mg}$
(63\%, single crystals). NMR: Due to the low solubility or decomposition in organic solvents, no meaningful spectrum could be recorded. IR (Nujol): $v\left(\mathrm{~cm}^{-1}\right)=2725(\mathrm{w}), 1558(\mathrm{w})$, $1301(w), 1259$ (w), $1241(w), 1184(w), 1091(w), 1028(w), 801$ $(\mathrm{w}), 721(\mathrm{w}), 693(\mathrm{w})$. Elemental analysis calcd (\%) for $\left[\mathrm{C}_{56} \mathrm{H}_{47} \mathrm{~N}_{2} \mathrm{P}_{3} \mathrm{PtSn}\right](1154.72 \mathrm{~g} / \mathrm{mol}): \mathrm{C}_{58.25}, \mathrm{H}$ 4.10, N 2.43; found $\mathrm{C}_{5} 8.94, \mathrm{H} 4.01, \mathrm{~N} 2.43$.

\section{ASSOCIATED CONTENT}

Supporting Information: Supporting Information including experimental, spectroscopic and crystallographic details are available free of charge via the Internet at http://pubs.acs.org.

\section{Accession Codes}

CCDC $1867126-1867135$ contain the supplementary crystallographic data for this paper. These data can be obtained free of charge via www.ccdc.cam.ac.uk/data request/cif, or by emailing data request@ccdc.cam.ac.uk, or by contacting The Cambridge Crystallographic Data Center, 12 Union Road, Cambridge CB2 1EZ UK; fax: +44 1223336033.

\section{AUTHOR INFORMATION}

\section{Corresponding Author}

* Prof. Dr. Jose M. Goicoechea

E-Mail: jose.goicoechea@chem.ox.ac.uk

ORCID

Sebastian Bestgen: oooo-0oo2-3462-6197

Jose M. Goicoechea: oooo-0oo2-7311-1663

Notes

The authors declare no competing financial interest.

\section{ACKNOWLEDGMENTS}

S.B. gratefully acknowledges the Deutsche Forschungsgemeinschaft (DFG, BE 6401/1-1) (Project number 380155090) for a generous fellowship as well as the Karlsruhe Nano Micro Facility (KNMF), a Helmholtz Research Infrastructure at Karlsruhe Institute of Technology (Proposal-ID 2017-019020910), for beam time.

\section{REFERENCES}

1. Nesterov, V.; Reiter, D.; Bag, P.; Frisch, P.; Holzner, R.; Porzelt, A.; Inoue, S., NHCs in Main Group Chemistry. Chem. Rev. 2018, 118 (19), 9678-9842.

2. $\quad \mathrm{N}$-Heterocyclic Carbenes in Transition Metal Catalysis. Springer: Berlin Heidelberg New York, 2007; Vol. 21.

3. N-Heterocyclic Carbenes : From Laboratory Curiosities to Efficient Synthetic Tools. The Royal Society of Chemistry: Cambridge, 2011; Vol. 6.

4. $\quad \mathrm{N}$-Heterocyclic Carbenes in Transition Metal Catalysis and Organocatalysis. Springer: Dordrecht Heidelberg London New York, 2011; Vol. 32.

5. Peris, E., Smart N-Heterocyclic Carbene Ligands in Catalysis. Chem. Rev. 2018, 118 (19), 9988-10031.

$6 . \quad$ Kuhl, O., The chemistry of functionalised N-heterocyclic

carbenes. Chem. Soc. Rev. 2007, 36 (4), 592-607.

7. Yuan, D.; Tang, H.; Xiao, L.; Huynh, H. V., CSC-pincer versus pseudo-pincer complexes of palladium(ii): a comparative study on complexation and catalytic activities of NHC complexes. Dalton Trans. 2011, 40 (35), 8788-8795.

8. Gaillard, S.; Renaud, J.-L., When phosphorus and NHC (Nheterocyclic carbene) meet each other. Dalton Trans. 2013, $4_{2}^{2}$ (20), 7255-7270. 
9. John, A.; Ghosh, P., Fascinating frontiers of N/Ofunctionalized N-heterocyclic carbene chemistry: from chemical catalysis to biomedical applications. Dalton Trans. 2010, 39 (31), 7183-7206.

10. Normand, A. T.; Cavell, K. J., Donor-Functionalised NHeterocyclic Carbene Complexes of Group 9 and 10 Metals in Catalysis: Trends and Directions. Eur. J. Inorg. Chem. 20o8, 2008 (18), 2781-280o.

11. Herrmann, W. A.; Denk, M.; Behm, J.; Scherer, W.; Klingan, F. R.; Bock, H.; Solouki, B.; Wagner, M., Stable Cyclic Germanediyls ("Cyclogermylenes"): Synthesis, Structure, Metal Complexes, and Thermolyses. Angew. Chem. Int. Ed. 1992, 31 (11), $1485-1488$.

12. Tomasik, A. C.; Hill, N. J.; West, R., Synthesis and characterization of three new thermally stable N-heterocyclic germylenes. J. Organomet. Chem. 2009, 694 (13), 2122-2125. 13. van der Boom, M. E.; Milstein, D., Cyclometalated Phosphine-Based Pincer Complexes: Mechanistic Insight in Catalysis, Coordination, and Bond Activation. Chem. Rev. 2003, 103 (5), 1759-1792.

14. Benedek, Z.; Szilvási, T., Theoretical Assessment of LowValent Germanium Compounds as Transition Metal Ligands: Can They Be Better than Phosphines or NHCs? Organometallics 2017, 36 (8), 1591-16oo.

15. $\quad$ Álvarez-Rodríguez, L.; Cabeza, J. A.; García-Álvarez, P.; Polo, D., The transition-metal chemistry of amidinatosilylenes, germylenes and -stannylenes. Coord. Chem. Rev. 2015, 30o, 1-28. 16. Schäfer, S.; Köppe, R.; Gamer, M. T.; Roesky, P. W., Zincsilylene complexes. Chem. Commun. 2014, 50 (77), 11401-11403. 17. Blom, B.; Stoelzel, M.; Driess, M., New Vistas in NHeterocyclic Silylene (NHSi) Transition-Metal Coordination Chemistry: Syntheses, Structures and Reactivity towards Activation of Small Molecules. Chem. Eur. J. 2013, 19 (1), 40-62.

18. Leung, W.-P.; Kan, K.-W.; Chong, K.-H., Reactions of some organogermanium(II) chlorides. Coord. Chem. Rev. 2007, 251 (17), 2253-2265.

19. Gallego, D.; Inoue, S.; Blom, B.; Driess, M., Highly Electron-Rich Pincer-Type Iron Complexes Bearing Innocent Bis(metallylene)pyridine Ligands: Syntheses, Structures, and Catalytic Activity. Organometallics 2014, 33 (23), 6885-6897. 20. Metsanen, T. T.; Gallego, D.; Szilvasi, T.; Driess, M.; Oestreich, M., Peripheral mechanism of a carbonyl hydrosilylation catalysed by an SiNSi iron pincer complex. Chem. Sci. 2015, 6 (12), 7143-7149.

21. $\quad$ Brück, A.; Gallego, D.; Wang, W.; Irran, E.; Driess, M.; Hartwig, J. F., Pushing the $\sigma$-Donor Strength in Iridium Pincer Complexes: Bis(silylene) and Bis(germylene) Ligands Are Stronger Donors than Bis(phosphorus(III)) Ligands. Angew. Chem. Int. Ed. 2012, 51 (46), 11478-11482.

22. Gallego, D.; Brück, A.; Irran, E.; Meier, F.; Kaupp, M.; Driess, M.; Hartwig, J. F., From Bis(silylene) and Bis(germylene) Pincer-Type Nickel(II) Complexes to Isolable Intermediates of the Nickel-Catalyzed Sonogashira Cross-Coupling Reaction. J. Am. Chem. Soc. 2013, 135 (41), 15617-15626.

23. Wang, W.; Inoue, S.; Enthaler, S.; Driess, M., Bis(silylenyl)- and Bis(germylenyl)-Substituted Ferrocenes: Synthesis, Structure, and Catalytic Applications of Bidentate Silicon(II)-Cobalt Complexes. Angew. Chem. Int. Ed. 2012, 51 (25), 6167-6171.

24. Someya, C. I.; Haberberger, M.; Wang, W.; Enthaler, S.; Inoue, S., Application of a Bis(silylene) Nickel Complex as Precatalyst in C-C Bond Formation Reactions. Chem. Lett. 2013, 42 (3), 286-288.

25. Alvarez-Rodriguez, L.; Brugos, J.; Cabeza, J. A.; GarciaAlvarez, P.; Perez-Carreno, E.; Polo, D., Synthesis and initial transition metal chemistry of the first PGeP pincer-type germylene. Chem. Commun. 2017, 53 (5), 893-896.

26. Âlvarez-Rodríguez, L.; Brugos, J.; Cabeza, J. A.; GarcíaÁlvarez, P.; Pérez-Carreño, E., From a Diphosphanegermylene to Nickel, Palladium, and Platinum Complexes Containing Germyl PGeP Pincer Ligands. Chem. Eur. J. 2017, 23 (60), 15107-15115.
27. Brugos, J.; Cabeza, J. A.; García-Álvarez, P.; Pérez-Carreño, E.; Polo, D., Synthesis and some coordination chemistry of the PSnP pincer-type stannylene $\mathrm{Sn}\left(\mathrm{NCH}_{2} \mathrm{P}_{\mathrm{Bu}}\right)_{2} \mathrm{C}_{6} \mathrm{H}_{4}$, attempts to prepare the $\mathrm{PSiP}$ analogue, and the effect of the $\mathrm{E}$ atom on the molecular structures of $\mathrm{E}\left(\mathrm{NCH}_{2} \mathrm{P} t \mathrm{Bu}_{2}\right)_{2} \mathrm{C}_{6} \mathrm{H}_{4}(\mathrm{E}=\mathrm{C}, \mathrm{Si}, \mathrm{Ge}, \mathrm{Sn})$. Dalton Trans. 2018, 47 (13), 4534-4544.

$28 . \quad$ Krebs, K. M.; Freitag, S.; Maudrich, J. J.; Schubert, H.; Sirsch, P.; Wesemann, L., Coordination chemistry of stannylenebased Lewis pairs - insertion into $\mathrm{M}-\mathrm{Cl}$ and $\mathrm{M}-\mathrm{C}$ bonds. From base stabilized stannylenes to bidentate ligands. Dalton Trans. 2018, 47 (1), 83-95.

29. $\quad$ Bestgen, S.; Gamer, M. T.; Lebedkin, S.; Kappes, M. M.; Roesky, P. W., Di- and Trinuclear Gold Complexes of

Diphenylphosphinoethyl-Functionalised Imidazolium Salts and their N-Heterocyclic Carbenes: Synthesis and Photophysical Properties. Chem. Eur. J. 2015, 21 (2), 601-614.

30. Kaub, C.; Lebedkin, S.; Bestgen, S.; Köppe, R.; Kappes, M. M.; Roesky, P. W., Defined tetranuclear coinage metal chains. Chem. Commun. 2017, 53 (69), 9578-9581.

31. Kiefer, C.; Bestgen, S.; Gamer, M. T.; Kühn, M.; Lebedkin, S.; Weigend, F.; Kappes, M. M.; Roesky, P. W., Coinage Metal Complexes of Bis-Alkynyl-Functionalized N-Heterocyclic Carbenes: Reactivity, Photophysical Properties, and Quantum Chemical Investigations. Chem. Eur. J. 2017, 23 (7), 1591-1603.

32. Day, G. S.; Pan, B.; Kellenberger, D. L.; Foxman, B. M.;

Thomas, C. M., Guilty as charged: non-innocent behavior by a pincer ligand featuring a central cationic phosphenium donor. Chem. Commun. 2011, 47 (12), 3634-3636.

33. Pan, B.; Evers-McGregor, D. A.; Bezpalko, M. W.; Foxman, B. M.; Thomas, C. M., Multimetallic Complexes Featuring a Bridging N-heterocyclic Phosphido/Phosphenium Ligand: Synthesis,

Structure, and Theoretical Investigation. Inorg. Chem. 2013, 52 (16), 9583-9589.

34. Pan, B.; Xu, Z.; Bezpalko, M. W.; Foxman, B. M.; Thomas, C. M., N-Heterocyclic Phosphenium Ligands as Sterically and Electronically-Tunable Isolobal Analogues of Nitrosyls. Inorg. Chem. 2012, 51 (7), 4170-4179.

35. Poitras, A. M.; Knight, S. E.; Bezpalko, M. W.; Foxman, B. M.; Thomas, C. M., Addition of $\mathrm{H}_{2}$ Across a Cobalt-Phosphorus Bond. Angew. Chem. Int. Ed. 2018, 57 (6), 1497-1500.

36. Pan, B.; Pierre, S.; Bezpalko, M. W.; Napoline, J. W.; Foxman, B. M.; Thomas, C. M., Isolation of N-Heterocyclic Alkyl Intermediates en Route to Transition Metal N-Heterocyclic Carbene Complexes: Insight into a C-H Activation Mechanism.

Organometallics 2013, 32 (2), 704-710.

37. $\quad$ Evers-McGregor, D. A.; Bezpalko, M. W.; Foxman, B. M.; Thomas, C. M., N-heterocyclic phosphenium and phosphido nickel complexes supported by a pincer ligand framework. Dalton Trans. 2016, 45 (5), 1918-1929.

38. Knight, S. E.; Bezpalko, M. W.; Foxman, B. M.; Thomas, C. M., Coordination of N-heterocyclic phosphine- and phospheniumcontaining pincer ligands to copper(I): Evidence for reactive electrophilic metal-phosphenium intermediates. Inorg. Chim. Acta 2014, 422, 181-187.

39. Pan, B.; Bezpalko, M. W.; Foxman, B. M.; Thomas, C. M., Coordination of an N-Heterocyclic Phosphenium Containing Pincer Ligand to a $\mathrm{Co}(\mathrm{CO})_{2}$ Fragment Allows Oxidation To Form an Unusual N-Heterocyclic Phosphinito Species. Organometallics 2011, 30 (21), 5560-5563.

40. Henning, J.; Schubert, H.; Eichele, K.; Winter, F.; Pöttgen, R.; Mayer, H. A.; Wesemann, L., Synthesis and Characterization of $\mathrm{N}-\left[2-\mathrm{P}(i-\mathrm{Pr})_{2}-4 \text {-methylphenyl }\right]_{2}^{-}$(PNP) Pincer Tin(IV) and Tin(II) Complexes. Inorg. Chem. 2012, 51 (10), 5787-5794.

41. Arduengo, A. J.; Goerlich, J. R.; Marshall, W. J., A stable diaminocarbene. J. Am. Chem. Soc. 1995, 117 (44), 11027-11028.

42. West, R.; Denk, M., Stable silylenes: Synthesis, structure, reactions. Pure Appl. Chem. 1996, 68 (4), 785-788.

43. Walz, F.; Moos, E.; Garnier, D.; Köppe, R.; Anson, C. E.; Breher, F., A Redox-Switchable Germylene and its Ligating Properties in Selected Transition Metal Complexes. Chem. Eur. J. 2017, 23 (5), 1173-1186. 
44. Gans-Eichler, T.; Gudat, D.; Nieger, M., Tin Analogues of

"Arduengo Carbenes": Synthesis of 1,3,2 $\lambda^{2}$-Diazastannoles and

Transfer of Sn Atoms between a 1,3,2 $\lambda^{2}$-Diazastannole and a

Diazadiene. Angew. Chem. Int. Ed. 2002, 41 (11), 1888-1891.

45. Freitag, S.; Krebs, K. M.; Henning, J.; Hirdler, J.; Schubert,

H.; Wesemann, L., Stannylene-Based Lewis Pairs. Organometallics

2013, 32 (22), 6785-6791.

46. $\quad$ Freitag, S.; Henning, J.; Schubert, H.; Wesemann, L.,

Phosphastannirane: A Phosphorus/Tin(II) Lewis Pair that Undergoes

Alkyne and Alkene Addition. Angew. Chem. Int. Ed. 2013, 52 (21),

5640-5643.

47. Waters, J. B.; Goicoechea, J. M., Alkali metal salts of

ditopic carbanionic carbenes as reagents for the synthesis of novel

complexes of group 12 and 14 metals. Dalton Trans. 2014, 43 (38),

$14239-14248$.

48. Álvarez-Rodríguez, L.; Cabeza, J. A.; García-Âlvarez, P.;

Polo, D., Amidinatogermylene Complexes of Copper, Silver, and

Gold. Organometallics 2015, 34 (22), 5479-5484.

49. Zhao, N.; Zhang, J.; Yang, Y.; Chen, G.; Zhu, H.; Roesky, H. W., Reactivity Studies of (Phenylethynyl)germylene $\mathrm{LGeC} \equiv \mathrm{CPh}(\mathrm{L}=$ $\mathrm{HC}\left[\mathrm{C}(\mathrm{Me}) \mathrm{N}-2,6-i \mathrm{Pr}_{2} \mathrm{C}_{6} \mathrm{H}_{3}\right]_{2}$ ) toward Pentafluorophenylcopper(I), silver(I), and -gold(I) Complexes. Organometallics 2013, 32 (3), 762769

50. $\quad$ Che, C.-M.; Mao, Z.; Miskowski, V. M.; Tse, M.-C.; Chan, C.-K.; Cheung, K.-K.; Phillips, D. L.; Leung, K.-H., Cuprophilicity: Spectroscopic and Structural Evidence for $\mathrm{Cu}-\mathrm{Cu}$ Bonding Interactions in Luminescent Dinuclear Copper(I) Complexes with Bridging Diphosphane Ligands. Angew. Chem. Int. Ed. 20oo, 39 (22), 4084-4088.

51. Harisomayajula, N. V. S.; Wu, B. H.; Lu, D. Y.; Kuo, T. S.; Chen, I. C.; Tsai, Y. C., Ligand-Unsupported Cuprophilicity in the Preparation of Dodecacopper(I) Complexes and Raman Studies. Angew. Chem. Int. Ed. 2018, 57 (31), 9925-9929.

52. Zabula, A. V.; Pape, T.; Hepp, A.; Hahn, F. E.,

Coordination chemistry of bisstannylenes with platinum(o). Dalton

Trans. 2008, (43), 5886-9o. 
TOC: The synthesis and application of two phosphine-functionalized pincer-type N-heterocyclic carbene analogues [(PNNP)E] $(\mathrm{E}=\mathrm{Ge}, \mathrm{Sn})$ and their reactivity towards divalent main group as well as precious metal compounds was investigated. Due to the flexibility of the ligand scaffold, both pincer-type and polynuclear metal clusters were obtained.

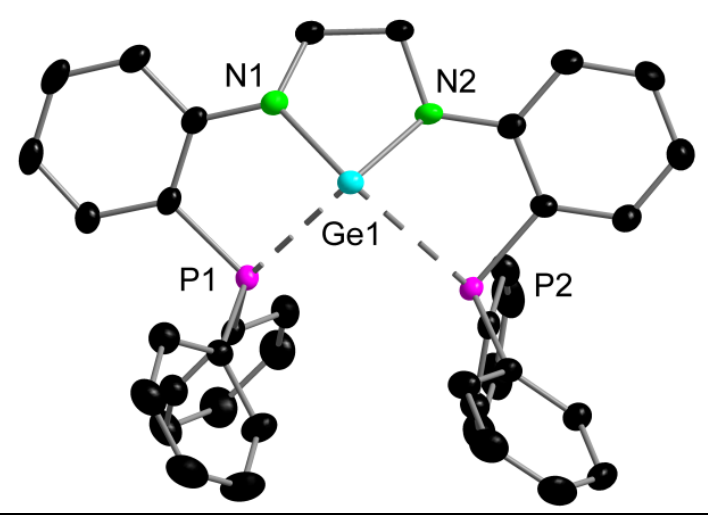

